\title{
Microlicieae (Melastomataceae) no município de Mucugê, Chapada Diamantina, Bahia, Brasil
}

\author{
Microlicieae (Melastomataceae) from the municipality of Mucugê, \\ Chapada Diamantina, Bahia, Brazil
}

Luciano Pataro ${ }^{1,4}$, Rosana Romero ${ }^{2}$ \& Nádia Roque ${ }^{3}$

\begin{abstract}
Resumo
O presente estudo fornece o tratamento taxonômico das espécies de Microlicieae para o município de Mucugê, Chapada Diamantina, Bahia, Brasil. Foram catalogadas 27 espécies distribuídas nos gêneros Microlicia (24 espécies), Lavoisiera (L. harleyi e L. nervulosa) e Trembleya (T. parviflora). Com exceção de M. fasciculata, M. viminalis e T. parviflora, as demais espécies encontradas em Mucugê são endêmicas da Chapada Diamantina. Entre as espécies de Microlicia, quatro foram recentemente descritas e outras quatro ainda necessitam de estudos complementares para sua identificação. Anteras poliesporangiadas foram descritas pela primeira vez para 11 espécies de Microlicia. As espécies de Microlicieae ocupam áreas de campo rupestre em altitudes entre 900-1.500 m, em solos arenosos ou pedregosos, às vezes associadas a cursos d'água.
\end{abstract}

Palavras-chave: campos rupestres, endemismos, flora da Bahia, Lavoisiera, Microlicia, Trembleya.

\begin{abstract}
This study provides a taxonomic survey of Microlicieae tribe in the Mucugê municipality, Chapada Diamantina, Bahia, Brazil. We identified 27 species belonging to three genera: Lavoisiera (L. harleyi and L. nervulosa), Microlicia (24 species) and Trembleya parviflora. Except for Microlicia fasciculata, M. viminalis and Trembleya parviflora, the others species found in Mucugê are endemic to Chapada Diamantina, Bahia. Among the species of Microlicia, four were recently described, and four others still require further studies for its identification. Polysporangiate anthers were described for the first time for 11 species of Microlicia. The species of Microlicieae are found mainly in rocky field vegetation, between $900-1.500 \mathrm{~m}$ altitude, in sandy or rocky soils, sometimes associated to water streams.
\end{abstract}

Key words: rocky fields, endemism, flora of Bahia, Lavoisiera, Microlicia, Trembleya.

\section{Introdução}

A Cadeia do Espinhaço apresenta-se como uma formação montanhosa do Brasil Central, estendendo-se por $1.100 \mathrm{~km}$, desde o estado de Minas Gerais (correspondente à Serra do Espinhaço) até a Bahia, onde é denominada de Chapada Diamantina. Esta cadeia de montanhas data do Pré-Cambriano, quando diversas classes de solo se formaram, dentre eles os Neossolos, onde se desenvolvem os campos rupestres (Nolasco et al. 2008). Esta fitofisionomia caracteriza-se pela presença de espécies tipicamente herbáceas e arbustivas, normalmente encontradas em altitudes superiores a $800 \mathrm{~m}$ e estendendo-se sobre afloramentos rochosos (Harley 1995). Esta tipologia abriga grande diversidade de espécies de Asteraceae, Bromeliaceae, Eriocaulaceae, Melastomataceae, Orchidaceae e Velloziaceae, entre outras (Rapini et al. 2008).

A família Melastomataceae é um grupo monofilético, constituído por 150-166 gêneros e ca. de 4.750 espécies com distribuição pantropical, das quais ca. de 3.000 são encontradas nos neotrópicos (Clausing \& Renner 2001). Microlicieae é

\footnotetext{
${ }^{1}$ Universidad Autónoma de Madrid, Depto. Biología (Botánica), Calle Darwin 2, 28049, Madrid, España.

${ }^{2}$ Universidade Federal de Uberlândia, Inst. Biologia, R. Ceará s/n, Campus Umuarama, 38400-901, Uberlândia, MG, Brasil. rosanaromero5@gmail.com

${ }^{3}$ Universidade Federal da Bahia, Inst. Biologia, Depto. Botânica, R. Barão de Jeremoabo s/n, Campus Universitário de Ondina, 40170-115, Salvador, BA, Brasil.

${ }^{4}$ Autor para correspondência: luciano.pataro@gmail.com
} 
monofilética (Fritsch et al. 2004), tratando-se de uma das principais tribos da família nas formações campestres brasileiras (Almeda \& Martins 2001), com ca. de 203 espécies, das quais aproximadamente $90 \%$ são endêmicas do bioma Cerrado (BFG 2015). Grande parte das espécies está distribuída nos campos rupestres dos estados de Minas Gerais e Bahia (Fritsch et al. 2004). Representantes da tribo são reconhecidos pelo hábito arbustivo, folhas geralmente imbricadas, com indumento variado, estames na maioria das vezes dimorfos, geralmente com o conectivo prolongado, com apêndice ventral, ovário glabro, frutos capsulares, com numerosas sementes, reniformes, de superfície foveolada (Almeda \& Martins 2001; Fritsch et al. 2004). As espécies têm distribuição centrada na América do Sul, com exceção de duas espécies de Rhynchanthera DC. que ocorrem na América Central (Renner 1990; Fritsch et al. 2004). Chaetostoma DC., Lavoisiera DC., Stenodon Naudin e Trembleya DC. são gêneros endêmicos do Brasil, enquanto que Microlicia D.Don, com 126 espécies (BFG 2015), apresenta apenas três espécies que não ocorrem no Brasil, e Poteranthera Bong., com duas espécies que ocorrem na Venezuela (Kribel 2012) e Bolívia (Rocha et al. 2016).

Considerando a diversidade da tribo no Brasil, o presente estudo tem como objetivo fornecer o tratamento taxonômico da tribo Microlicieae (Melastomataceae) no município de Mucugê, Chapada Diamantina, Bahia, apresentando chave de identificação para as espécies, ilustrações, comentários taxonômicos e de distribuição geográfica.

\section{Material e Métodos}

O município de Mucugê, com área total de $2.455 \mathrm{~km}^{2}$, faz parte do Parque Nacional da Chapada Diamantina (Fig. 1), localizado aos 1305' 'S, 41'22'19' W (Harley \& Simons 1986). Apresenta um mosaico de tipos vegetacionais, com manchas de cerrado, caatinga, florestas estacionais e, principalmente, áreas campestres, dentre elas os campos rupestres, fitofisionomia predominante em Mucugê. A precipitação média anual varia de $800-1.100 \mathrm{~mm}$, concentradas nos meses de novembro a janeiro, enquanto que a temperatura média anual é de $19,5^{\circ} \mathrm{C}$ (Harley \& Simons 1986).

Entre maio de 2010 a junho de 2011 foram realizadas coletas bimestrais de espécimes botânicos, percorrendo diferentes áreas do município de Mucugê, a fim de abranger fitofisionomias distintas. Houve um maior esforço de coleta nos campos rupestres devido à sua predominância no município. Também foram analisadas coleções depositadas nos herbários ALCB, CEPEC, HRB, HUEFS, HUFU, NY, R, RB, SP, SPF, UEC e US. A identificação dos espécimes foi feita com base em Cogniaux (1883), Renner (1990), Martins (1997), Romero (2003), Woodgyer (2005) e Koschnitzke \& Martins (2006), bem como em análises da coleção-tipo e de imagens dos tipos. A circunscrição da tribo segue Fritsch et al. (2004). Foi utilizado o material da área de estudo para a circunscrição do gênero e das espécies. A descrição da morfologia das folhas baseou-se em Radford et al. (1986). Para o pecíolo foram adotadas as seguintes terminologias: folha séssil (pecíolo ausente); folha subséssil (pecíolo $=0,1-0,5 \mathrm{~mm}$ compr.); folha peciolada (pecíolo $\geq 0,6 \mathrm{~mm}$ compr.). Estudos recentes (Romero \& Castro 2014; Romero et al. 2015a; Romero et al. 2015b) revelaram que as glândulas sésseis que

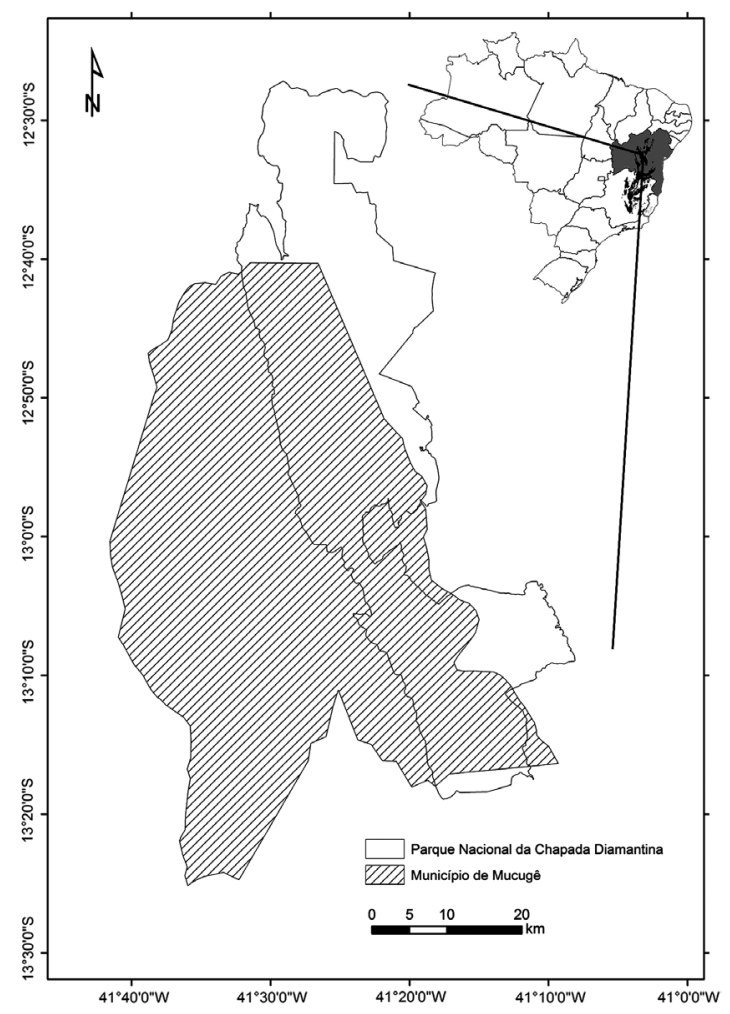

Figura 1 - Mapa da localização do município de Mucugê no Parque Nacional da Chapada Diamantina, Bahia, Brasil.

Figure 1 - Map showing the location of the municipality of Mucugê, in the Chapada Diamantina National Park, Bahia, Brazil. 
compõem o indumento da maioria das espécies de Microlicia apresentam um pedúnculo curto, o qual é visível apenas por meio de cortes anatômicos. No presente trabalho optou-se por descrevê-las como glândulas esféricas.

\section{Resultados e Discussão}

A tribo Microlicieae está representada no município de Mucugê por 27 espécies distribuídas em três gêneros: Microlicia (24 spp.), Lavoisiera (2 spp.) e Trembleya (1 sp.). Representantes da tribo ocupam geralmente áreas de campo rupestre, algumas vezes associadas a cursos d'água. Microlicia é o gênero com maior diversidade, no qual quatro espécies foram descritas recentemente (Pataro et al. 2013). Quatro espécimes de Microlicia ainda não foram determinados a nível específico e necessitam de estudos mais detalhados para uma correta identificação.

Dentre as espécies de Microlicieae catalogadas para Mucugê, 24 são endêmicas da Chapada Diamantina. Destas, L. nervulosa Naudin, M. intercalycina Pataro \& R.Romero, M. macropetala Pataro \& R.Romero, $M$. pulchra Pataro \& R.Romero, Microlicia sp. 1, Microlicia sp. 2, Microlicia sp. 3 e Microlicia sp. 4 apresentam registros somente para Mucugê, sendo provavelmente endêmicas desse município. Microlicia noblickii (Wurdack) A.B.Martins \& Almeda, até então conhecida apenas do município de Palmeiras, teve sua distribuição ampliada para Mucugê.

Baumgratz et al. (1996) descreveram pela primeira vez as anteras poliesporangiadas em Melastomataceae para 16 espécies de Microlicia. Posteriormente, este tipo de antera foi relatado para mais 20 espécies do gênero (Rodrigues
2005; Woodgyer 2005; Woodgyer \& Zappi 2009; Almeda \& Martins 2012; Pataro et al. 2013; Romero \& Woodgyer 2014). No presente estudo, este caráter foi descrito pela primeira vez para mais oito espécies: $M$. baccharoides, M. comparilis, M. leucopetala, M. lutea, $M$. longisepala, $M$. neglecta, $M$. pinheiroi e $M$. torrendii, além de Microlicia sp. 1, Microlicia sp. 3 e Microlicia sp. 4.

Vale destacar que $M$. pulchra é a única espécie deste gênero que apresenta columela persistente no fruto (Pataro et al. 2013), caráter reportado anteriormente apenas para espécies de Lavoisiera (Almeda \& Martins 2001).

Microlicieae Naudin, Ann. Sci. Nat., Bot., sér. 3, 12: 203. 1849.

Arbustos, subarbustos ou arvoretas. Ramos quadrangulares ou cilíndricos, glabros ou pilosos. Folhas sésseis, subsésseis ou pecioladas, glabras ou pilosas, uninérveas ou com 1-5 pares de nervuras acródromas basais. Flores em dicásios axilares ou solitárias, terminais ou axilares. Flores 5-6-meras; sésseis ou pediceladas. Hipanto 10-estriado, 10-costado ou liso, glabro ou piloso. Cálice com tubo ca. 0,2 mm. Pétalas alvas, creme, amarelas, lilases, róseas ou magenta. Estames 10 16 iso a dimorfos; filetes glabros; anteras oblongas ou ovais, poliesporangiadas ou tetraesporangiadas; conectivo prolongado abaixo das tecas, apêndice ventral presente. Ovário súpero ou semi-ínfero, oval, oboval, piriforme ou cilíndrico, 3-6 locular; estilete filiforme, curvo ou ereto, glabro; estigma punctiforme. Cápsula loculicida, globosa, elíptica ou oval, comumente envolta pelo hipanto, columela persistente ou decídua. Sementes numerosas, reniformes, superfície foveolada.

\section{Chave de identificação das espécies de Microlicieae do município de Mucugê}

1. Flores 6-meras; cápsula com deiscência da base em direção ao ápice.

2. Lâmina foliar 40-43 × 20-22 mm; pétalas magentas. 1.1. Lavoisiera harleyi

2'. Lâmina foliar 23-25 × 8-9 mm; pétalas amarelas 1.2. Lavoisiera nervulosa

1'. Flores 5-meras; cápsula com deiscência do ápice em direção à base.

3. Flores em dicásios, axilares 3.1. Trembleya parviflora

3'. Flores solitárias, terminais.

4. Pétalas amarelas ou creme.

5. Folha com 1 par de nervuras acródromas; flores com pedicelo 1-1,5 mm compr.; estilete 10-11 mm compr. 2.21. Microlicia sp. 1

5'. Folha uninérvea; flores sésseis ou com pedicelo ca. 0,5 $\mathrm{mm}$ compr.; estilete 5,5-8 $\mathrm{mm}$ compr. 
6. Margem foliar setoso-ciliada; cálice recoberto por glândulas esféricas, douradas, com 1(-2) tricoma simples entre as sépalas; sépalas 2-2,5 mm compr. 2.6. Microlicia intercalycina

6'. Margem foliar glabra; cálice recoberto apenas por glândulas esféricas, douradas, sem tricoma intercalado entre as sépalas; sépalas ca. $1 \mathrm{~mm}$ compr.

7. Margem foliar levemente revoluta; estames dimorfos. 2.9. Microlicia lutea

7'. Margem foliar plana; estames iso a subisomorfos 2.15. Microlicia parvula

4'. Pétalas alvas, lilales, rosas ou magentas.

8. Pétalas alvas.

9. Folhas sésseis ou subsésseis, com pecíolo ca. 0,5 mm compr.

10. Ramos, folhas, hipanto e sépalas densamente recobertos por tricomas setosos e por glândulas esféricas, douradas; pétalas 6,5-7,5 × 5-6 mm; estilete 5-5,5 mm compr., rosado 2.3. Microlicia fasciculata

10'. Ramos jovens, folhas, hipanto e sépalas recobertos apenas por glândulas esféricas, douradas; pétalas ca. $12 \times 7 \mathrm{~mm}$; estilete ca. $11 \mathrm{~mm}$ compr., amarelo

2.23. Microlicia sp. 3

9'. Folhas com pecíolo 2-5 $\mathrm{mm}$ compr.

11. Ramos e folhas recobertos por tricomas setosos, ca. $0,5 \mathrm{~mm}$ compr.; sépalas $1,5-2 \mathrm{~mm}$ compr.; estames antessépalos com conectivo prolongado $8-8,5 \mathrm{~mm}$ compr.; estilete $12-13,5 \mathrm{~mm}$ compr. 2.1. Microlicia baccharoides

11'. Ramos e folhas recobertos por tricomas setosos, 1-2 mm compr.; sépalas 4-6,5 mm compr.; estames antessépalos com conectivo prolongado $4-5 \mathrm{~mm}$ compr.; estilete $6-8$ mm compr.

12. Ramos e folhas recobertos por tricomas setosos, avermelhados e glândulas esféricas, douradas; lâmina foliar 2,5-6(-10) × 1-4(-7) mm; estames amarelos passando a avermelhados; ovário 3-locular. 2.7. Microlicia leucopetala

12'. Ramos e folhas recobertos por tricomas setosos, glandulares pedunculados e glândulas esféricas, todos dourados; lâmina foliar 16-18,5 × 8,5-9,5 mm; estames sempre amarelos; ovário 5-locular..... 2.5. Microlicia hirta

8'. Pétalas lilases, rosas ou magentas.

13. Folhas sésseis ou subsésseis, com pecíolo ca. 0,3 ou $0,5 \mathrm{~mm}$ compr.

14. Estames isomorfos.

15. Ramos, folhas, hipanto e sépalas recobertos por tricomas setosos (ca. $0,5 \mathrm{~mm}$ compr.) e glândulas esféricas, douradas; lâmina foliar 3-4 mm compr., margem revoluta . 2.2. Microlicia comparilis

15'. Ramos, folhas, hipanto e sépalas recobertos apenas por glândulas esféricas, douradas; lâmina foliar ca. 1,5 mm compr., margem plana. 2.11. Microlicia minima

14'. Estames dimorfos.

16. Margem foliar serreada, ciliado-glandulosa, tricomas glandulares pedunculados, ca. $1 \mathrm{~mm}$ compr.; sépalas recobertas por tricomas glandulares pedunculados, ca. 1 mm compr.

17. Pedicelo floral ca. $1,5 \mathrm{~mm}$ compr.; pétalas com a face abaxial apresentando uma faixa avermelhada em um dos lados, ápice glabro; anteras tetraesporangiadas; columela decídua. 2.4. Microlicia giuliettiana

17'. Pedicelo floral 2,5-3 mm compr.; pétalas com a face abaxial inteiramente magenta, ápice com um tricoma glandular pedunculado; anteras poliesporangiadas; columela persistente 2.17. Microlicia pulchra

16'. Margem foliar inteira ou crenada, glabra, raro ou comumente com tricomas glandulares pedunculados, ca. 0,2 $\mathrm{mm}$ compr.; sépalas recobertas por glândulas esféricas e/ou por tricomas glandulares pedunculados, ca. 0,2 $\mathrm{mm}$ compr.

18. Folha com 3-4 pares de nervuras sub-paralelódromas, margem foliar calosa, com tricomas glandulares pedunculados, ca. $0,2 \mathrm{~mm}$ compr. 
18'. Folha uninérvea ou com 1-2 pares de nervuras acródromas, margem foliar não calosa, glabra.

19. Lâmina foliar de base cordada; ovário 5-locular.

20. Lâmina foliar 6,5-8 × 4-6 mm, ápice arredondado; sépalas ca. $4 \mathrm{~mm}$ compr.; anteras tetraesporangiadas; conectivo dos estames antessépalos prolongado ca. $5 \mathrm{~mm}$ compr. .

2.12. Microlicia mucugensis

20'. Lâmina foliar 14-16 × 9-12,5 mm, ápice mucronado; sépalas 8-8,5 mm compr.; anteras poliesporangiadas; conectivo dos estames antessépalos prolongado $7-8 \mathrm{~mm}$.

2.14. Microlicia noblickii

19'. Lâmina foliar de base cuneada ou truncada; ovário 3-locular.

21. Lâmina foliar $12,5-15 \times 3-4 \mathrm{~mm}$; sépalas 6-8 mm compr., oblongas

2.24. Microlicia sp. 4

21'. Lâmina foliar 6-7,5 × 4,5-5,5 mm; sépalas ca. $3 \mathrm{~mm}$ compr., triangulares ......

2.18. Microlicia torrendii

13’. Folhas com pecíolo 0,5-1 mm compr.

22. Hipanto recoberto por glândulas esféricas ou por tricomas glandulares pedunculados.

23. Hipanto recoberto apenas por glândulas esféricas

24. Lâmina foliar 10-12 × 4-6 mm, margem plana, serreada, ciliado-setosa; sépalas ca. 6 mm compr. 2.8. Microlicia longisepala

24'. Lâmina foliar 5,5-7 × 1,5-2 mm, margem levemente revoluta, inteira; sépalas 3,5-4 mm compr. 2.16. Microlicia pinheiroi

23. Hipanto recoberto por tricomas glandulares pedunculados

25. Lâmina foliar 14-15,5 × 5-5,5 $\mathrm{mm}$; flores com pedicelo $0,5-1 \mathrm{~mm}$ compr.; conectivo dos estames antessépalos prolongado 8-9,5 mm; anteras poliesporangiadas; ovário 3-locular 2.13. Microlicia neglecta

25'. Lâmina foliar 7-9 × 3-5 mm; flores sésseis; conectivo dos estames antessépalos prolongado ca. $5 \mathrm{~mm}$; anteras tetraesporangiadas; ovário 4-locular.

2.22. Microlicia sp. 2

22'. Hipanto recoberto por glândulas esféricas e/ por tricomas setosos

26. Lâmina foliar 9-10 × 6-7 mm; pétalas 20-22,5 × 14-15,5 mm; estilete 11-12,5 mm compr. 2.10. Microlicia macropetala

26'. Lâmina foliar 5-7 × 3-4,5 mm; pétalas 7-7,5 × 5,5-6 mm; estilete 6-7 mm compr. 2.20. Microlicia wurdackiana

1. Lavoisiera DC., Prodr. 3: 102. 1828.

Arbustos ou arvoretas, ramificados, eretos. Ramos quadrangulares, glabros a pilosos, folhas geralmente concentradas no ápice dos ramos. Folhas verdes, sésseis, imbricadas, lâmina foliar com margem inteira, serreada, glabra ou ciliado-glandulosa, ambas as faces glabras ou apresentando tricomas esparsos; 1-3 pares de nervuras acródromas basais. Flores solitárias, terminais, 6-meras, terminais, sésseis ou curtamente pediceladas. Hipanto urceolado, constricto no ápice, glabro ou recoberto por tricomas glandulares pedunculados. Cálice formando um tubo ca. 0,2 $\mathrm{mm}$ compr. Sépalas oblongas ou triangulares, ápice agudo, algumas vezes aristado, margem inteira. Pétalas magentas ou amarelas, ápice agudo ou arredondado, margem inteira, glabras. Estames
12, dimorfos; filetes glabros, anteras oblongas, tetraesporangiadas; conectivo prolongado abaixo das tecas, apêndice ventral. Ovário livre ou parcialmente adnato ao hipanto, glabro, 6-locular; estilete glabro, estigma punctiforme. Cápsula loculicida, oval, 6-valvar, revestida pelo hipanto, deiscente da base em direção ao ápice, columela persistente. Sementes numerosas, reniformes, foveoladas.

Lavoisiera é um gênero endêmico do Brasil, com 41 espécies, a maioria delas ocorrendo no Cerrado, principalmente nos campos rupestres dos estados de Minas Gerais, Bahia e Goiás (Almeda \& Martins 2001; Fritsch et al. 2004; BFG 2015). Espécies de Lavoisiera diferenciam-se pelas flores 6-meras e cápsula deiscente da base em direção ao ápice (Almeda \& Martins 2001). 
1.1. Lavoisiera harleyi Wurdack, Phytologia 149(2): 147. 1981.

Arbusto ou arvoreta 1,5-2 m alt.; ramos jovens glabros, afilos na base. Folhas sésseis, ascendentes, concolores; lâmina 40-43 × 20-22 $\mathrm{mm}$, oboval, ápice agudo, margem inteira, base truncada, ambas as faces recobertas por tricomas setosos, esparsos, e por glândulas esféricas, douradas, 1 par de nervuras acródromas basais. Flores 6-meras, solitárias, terminais, sésseis. Hipanto ca. $11 \times 5 \mathrm{~mm}$, urceolado, glabro. Cálice com sépalas ca. $5 \mathrm{~mm}$ compr., oblongas, glabras, ápice agudo, aristado, arista ca. $1 \mathrm{~mm}$ compr. Pétalas 35-40 × 20-25 mm, magentas, obovais, ápice truncado ou emarginado. Estames 12, dimorfos, amarelos, os antessépalos com filete 12$13 \mathrm{~mm}$ compr., antera 3-3,5 mm compr., oblonga, tetraesporangiada, rostro ca. $0,5 \mathrm{~mm}$ compr., conectivo prolongado ca. $7 \mathrm{~mm}$ compr., apêndice ca. $2 \mathrm{~mm}$ compr., ápice truncado ou agudo, os antepétalos com filete ca. $11 \mathrm{~mm}$ compr., antera ca. $3 \mathrm{~mm}$ compr., oblonga, tetraesporangiada, rostro ca. $0,5 \mathrm{~mm}$ compr., conectivo prolongado 2-2,5 mm compr., magenta, apêndice ca. 1,5 mm compr., ápice truncado. Ovário ca. $6 \times 3,5 \mathrm{~mm}$, oval, 6-locular; estilete ca. $10 \mathrm{~mm}$ compr., magenta. Cápsula 12-13 × 8-9 mm. (Fig. 2c).

Material selecionado: Chapadinha, $13^{\circ} 13^{\prime} 13^{\prime \prime} \mathrm{S}$, 4199'9'W, 6.II.2005, fl., R. Funch 650 (HUEFS).

Material adicional: Rio de Contas, Pico das Almas, a 18 km a SW de Rio de Contas, $13^{\circ} 33$ 'S, 41 ${ }^{\circ} 57^{\prime} \mathrm{W}, 1600$ 1850 m, 22.VII.1979, fr., S.A. Mori et al. 12455 (US).

Lavoisiera harleyi é endêmica da Chapada Diamantina, ocorrendo nos campos rupestres dos municípios de Abaíra, Mucugê, Palmeiras e Rio de Contas (Santos \& Silva 2005). Coletada com flores de outubro a abril e com frutos em outubro. Diferencia-se de Lavoisiera nervulosa Naudin principalmente pelas folhas ascendentes (vs. horizontais), lâmina foliar maior (40-43 × 20-22 $\mathrm{mm}$ vs. $23-25 \times 8-9 \mathrm{~mm}$ ) e pétalas magentas (vs. amarelas).

1.2. Lavoisiera nervulosa Naudin, Ann. Sci. Nat., Bot., sér. 3, 2: 149. 1844.

Arbusto ou arvoreta, 2-4 m alt.; ramos recobertos por glândulas esféricas, afilos na base. Folhas sésseis, horizontais, concolores, levemente aromáticas; lâmina 23-25 × 8-9 mm, elíptica ou oval, ápice agudo, margem levemente revoluta, inteira, base truncada, ambas as faces recobertas por glândulas esféricas, douradas, folhas próximas às flores também com tricomas glandulares pedunculados, 2-3 pares de nervuras acródromas basais. Flores 6-meras, solitárias, terminais; pedicelo $0,5-1 \mathrm{~mm}$ compr. Hipanto 7-8 $\times 3-4,5$ $\mathrm{mm}$, urceolado, densamente recoberto na base por tricomas glandulares pedunculados, ca. $2 \mathrm{~mm}$ compr. Cálice com sépalas $2-3 \mathrm{~mm}$, triangulares, ápice agudo, terminado em um tricoma glandular pedunculado, ca. $2 \mathrm{~mm}$ compr. Pétalas 20$22 \times 12-13 \mathrm{~mm}$, amarelas, oblongas, ápice arredondado. Estames 12, dimorfos, amarelos, os antessépalos com filete ca. $12 \mathrm{~mm}$ compr., antera ca. $6 \mathrm{~mm}$ compr., oblonga, tetraesporangiada, rostro ca. $1 \mathrm{~mm}$ compr., conectivo prolongado 7-8 mm compr., apêndice ca. 2,5 mm compr., ápice bilobado, os antepétalos com filete 8-9 $\mathrm{mm}$ compr., antera ca. $6 \mathrm{~mm}$ compr., oblonga, tetraesporangiada, rostro ca. $1 \mathrm{~mm}$ compr., conectivo prolongado ca. $3 \mathrm{~mm}$ compr., apêndice ca. $2 \mathrm{~mm}$ compr., ápice bilobado. Ovário ca. $4 \times$ $2 \mathrm{~mm}$, oval, 6-locular; estilete ca. $6 \mathrm{~mm}$ compr., amarelo. Cápsula 9-10 × 5-7 mm. (Fig. 3a,b).

Material selecionado: Subida para Serra do Gobira, Gobira de Baixo, 132'95”'S, 41²1'75”'W, 14.III.2007, fr., K.F. Rodrigues 290 (UEC); Trilha para Torre do Capa

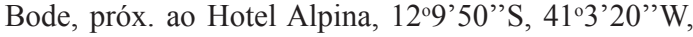
1165 m, 20.VII.2010, fl., N. Roque 2863 (ALCB).

Lavoisiera nervulosa é conhecida, até o momento, somente de Mucugê, onde provavelmente é endêmica. Encontrada em diferentes localidades do município, em cerrados de altitude e, principalmente, em campos rupestres. Coletada com flores entre os meses de março a outubro e com frutos de setembro a março. Facilmente reconhecida pelas flores amarelas e 6-meras. Para mais comentários ver L. harleyi.

2. Microlicia D.Don, Mem. Wern. Nat. His. Soc. 4(2): 301.1823

Subarbustos ou arbustos, eretos ou cespitosos, ramificados ou muito ramificados; ramos quadrangulares a cilíndricos, recobertos por tricomas dourados ou avermelhados, simples, glandulares sésseis ou pedicelados, ou glabros. Folhas verdes, sésseis, subsésseis ou pecioladas; lâminas geralmente pequenas, ovadas, elípticas ou oblongas; uninérveas ou 1-2 pares de nervuras acródromas basais, raro subparalelas. Flores 5-meras, sésseis ou curto-pediceladas, solitárias, terminais. Hipanto campanulado ou cilíndrico, 10-estriado, 10-costado ou liso, glabro ou recoberto por glândulas esféricas, douradas, tricomas glandulares pedunculados, e/ou tricomas setosos. Cálice formando um tubo ca. 0,2 $\mathrm{mm}$ compr. Sépalas oblongas, lanceoladas, triangulares, lineares ou estreito-triangulares. Pétalas magentas, 
lilases, rosas, alvas, ou amarelas, obovadas ou oblongas, ápice acuminado, agudo, arredondado ou assimétrico. Estames 10, isomorfos a dimorfos; filetes glabros; anteras oblongas ou ovadas, polisporangiadas ou tetraesporangiadas; conectivo prolongado abaixo da teca, apêndice ventral. Ovário 3-5-locular, oval, oboval ou piriforme, livre ao hipanto, glabro; estilete filiforme, curvo ou ereto; estigma punctiforme, glabro. Cápsula loculicida, globosa, elíptica ou oval, glabra, 3-5-valvar, deiscente do ápice em direção à base, comumente envolta pelo hipanto, columela persistente ou decídua. Sementes numerosas, reniformes, foveoladas.

Microlicia é o maior gênero da tribo Microlicieae, com aproximadamente 130 espécies (Romero 2013) concentradas nos campos rupestres do Brasil Central, principalmente nos estados da Bahia, Goiás e Minas Gerais (Almeda \& Martins 2001; Romero 2003; BFG 2015). Suas espécies são reconhecidas pelas flores 5-meras, ovário 3-5 locular e cápsula deiscente do ápice em direção à base (Almeda \& Martins 2001).

2.1. Microlicia baccharoides Mart. ex Naudin, Ann. Sci. Nat., Bot., sér. 3, 3: 174. 1845.

Arbusto 1,5-2 m alt.; ramos e folhas densamente recobertos por glândulas esféricas, douradas, e tricomas setosos com ca. $0,5 \mathrm{~mm}$ compr.; ramos jovens quadrangulares, os mais velhos cilíndricos, folhosos ao longo do comprimento. Folhas pecioladas, ascendentes, concolores; pecíolo 2-5 mm compr.; lâmina 12-15 $\times$ 9-11 mm, elíptica ou oval, ápice agudo, aristado, arista ca. 0,5 mm compr., margem crenada, base atenuada, 1 par de nervuras acródromas basais. Flores solitárias, terminais; pedicelo 0,5-1 mm compr. Hipanto ca. $5 \times 3 \mathrm{~mm}$, campanulado, liso, recoberto por glândulas esféricas. Cálice com sépalas 1,5-2 mm compr., triangulares, ápice agudo, apiculado, apículo ca. 0,5 mm compr., recobertas por glândulas esféricas. Pétalas 11,5-12 $\times$ 4-5 mm, alvas, obovais, ápice assimetricamente acuminado. Estames 10, dimorfos, amarelos, passando a avermelhados, os antessépalos com filete ca. $5 \mathrm{~mm}$ compr., antera ca. 3,5 mm compr., oblonga, poliesporangiada, rostro ca. $1 \mathrm{~mm}$ compr., conectivo prolongado 8-8,5 mm compr., apêndice 2-2,5 mm compr., ápice trilobado, os antepétalos com filete ca. $5 \mathrm{~mm}$ compr., antera ca. $3 \mathrm{~mm}$ compr., oblonga, poliesporangiada, rostro ca. $1 \mathrm{~mm}$ compr., conectivo prolongado ca. $2 \mathrm{~mm}$ compr., apêndice ca. $1 \mathrm{~mm}$ compr., ápice truncado. Ovário
2,5-3 × ca. 2 mm, oval, 3-locular; estilete 12-13,5 mm compr., creme. Cápsula ca. $4 \times 3 \mathrm{~mm}$, elíptica, 3-valvar, columela decídua. (Fig. 3a,b).

Material selecionado: Reserva do Projeto Sempre-Viva, Margem do Rio Piabinha, 1259'44”S, 41²0'51'”, 970 m, 21.I.2001, fl., R.M. Harley \& A.M. Giulietti 54066 (ALCB, HUEFS); Próximo ao Rio Piaba, 1257'2'”S, 4116'41'W, 848 m, 15.VII.2010, fl. e fr., M.L. Guedes et al. 17152 (ALCB).

Microlicia baccharoides é endêmica dos campos rupestres da Chapada Diamantina, ocorrendo nos municípios de Andaraí e Mucugê, onde é amplamente distribuída. Coletada com flores em julho e de novembro a maio e com frutos de julho a dezembro. Prontamente reconhecida pelos ramos e folhas recobertos por indumento denso de glândulas esféricas, douradas, e de tricomas setosos, flores com pétalas alvas e estames amarelos, tornando-se avermelhados com a maturidade. Microlicia baccharoides se assemelha a $M$. hirta Pataro \& R.Romero, da qual difere, principalmente, pelas sépalas menores (1,5-2 mm vs. 6-6,5 $\mathrm{mm}$ ) e prolongamento do conectivo dos estames antessépalos maiores (8-8,5 $\mathrm{mm}$ vs. 5-5,5 mm). Além disso, $M$. hirta apresenta estames sempre amarelos. Microlicia leucopetala Wurdack também apresenta pétalas alvas e estames passando de amarelo a avermelhados, mas difere de M. baccharoides pelo prolongamento do conectivo dos estames antessépalos menores (ca. 4,5 mm vs. 8-8,5 mm), sépalas maiores (4-5 mm vs. 1,5-2 $\mathrm{mm}$ ) e estilete menor (6-7 mm vs. $12-13,5 \mathrm{~mm})$.

2.2. Microlicia comparilis Wurdack, Phytologia 55(3): 136-137. 1984.

Arbusto ca. $1 \mathrm{~m}$ alt., cespitoso; ramos, folhas, hipanto e sépalas densamente recobertos por glândulas esféricas e tricomas setosos, com ca. 0,5 mm compr.; ramos jovens quadrangulares, os mais velhos cilíndricos, glabros, folhosos ao longo do comprimento. Folhas sésseis, ascendentes, concolores; lâmina 3-4 × 1-1,5 mm, lanceolada, ápice agudo, margem revoluta, inteira, glabra, base truncada, uninérvea. Flores solitárias, terminais; pedicelo ca. 0,5 mm compr. Hipanto 3-3,5 $\times$ 2-2,5 mm, campanulado, liso. Cálice com sépalas 2-2,5 mm compr., verdes, triangulares, ápice agudo. Pétalas 5-5,5 × 2,5-3 $\mathrm{mm}$, magentas, obovais ou oblongas, ápice assimetricamente acuminado. Estames 10, isomorfos, amarelos; filete ca. $3 \mathrm{~mm}$ compr., antera 2-2,5 mm compr., oval, poliesporangiada, rostro ca. 0,2 mm compr., conectivo prolongado ca. $1 \mathrm{~mm}$ compr., apêndice ca. 0,2 mm compr., ápice bilobado. Ovário ca. 1,5 


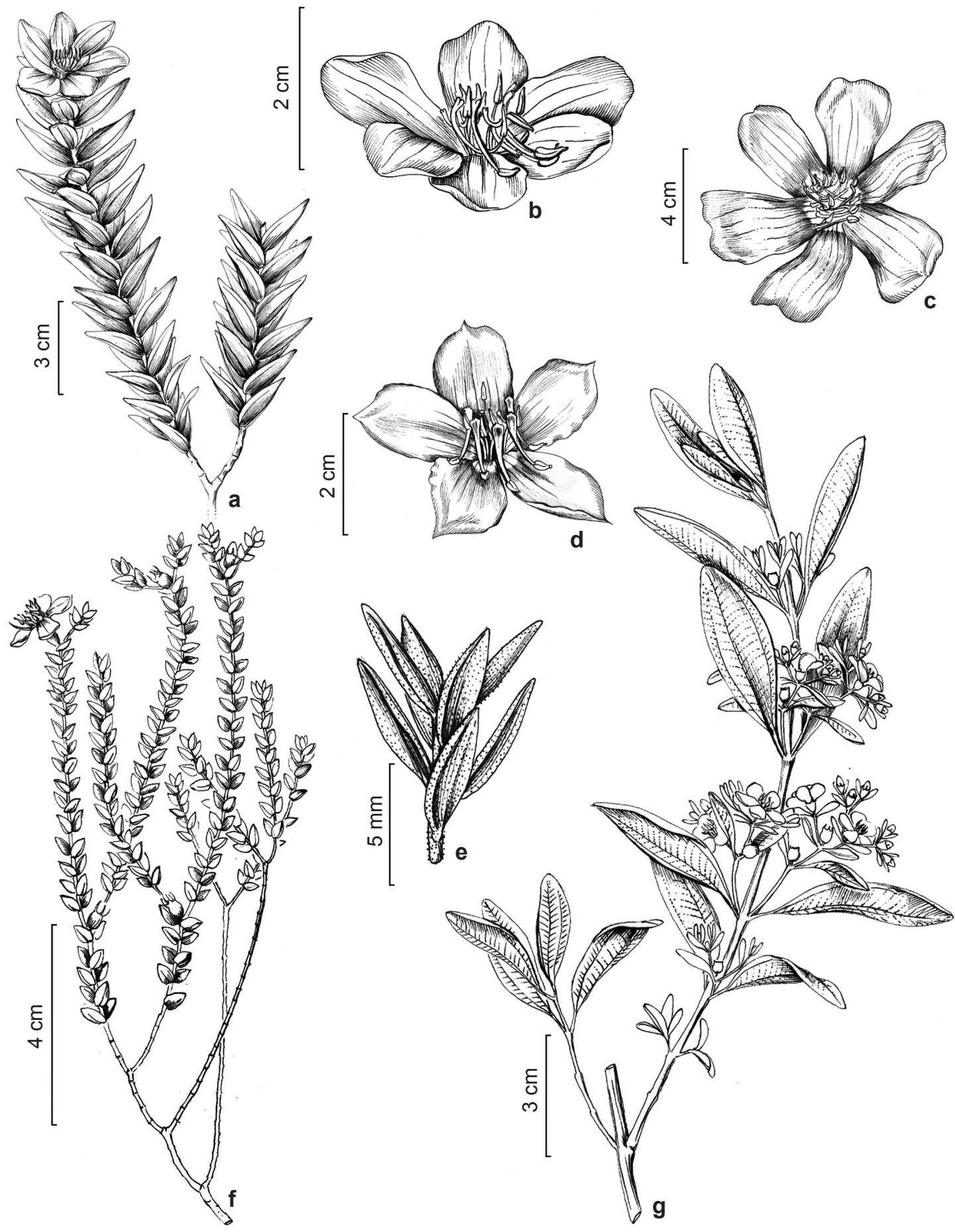

Figura 2 - a,b. Lavoisiera nervulosa - a. ramo florífero; b. flor. c. Lavoisiera harleyi - flor. d. Microlicia noblickii flor. e. Microlicia pinheiroi - ápice do ramo estéril. f. Microlicia sp. 3 - ramo florífero. g. Trembleya parviflora - ramo florífero. (a,b. N. Roque 2863; c. R. Funch 650; d. H.A. Ogasawara \& M. Alves 175; e. L. Pataro et al. 123; f. L. Pataro et al. 120; g. L. Pataro et al. 54).

Figure 2 - a,b. Lavoisiera nervulosa - a. flowering branch; b. flower. c. Lavoisiera harleyi - flower. d. Microlicia noblickii - flower. e. Microlicia pinheiroi - sterile branch apex. f. Microlicia sp. 3 - flowering branch. g. Trembleya parviflora-flowering branch. (a,b. N. Roque 2863; c. R. Funch 650; d. H.A. Ogasawara \& M. Alves 175; e. Pataro et al. 123; f. Pataro et al. 120; g. Pataro et al. 54). 
$\times 1 \mathrm{~mm}$, oboval ou cilíndrico, 3-locular; estilete ca. $6 \mathrm{~mm}$ compr., amarelo. Cápsula 2-2,5 × ca. 2 mm, elíptica, 3-valvar, columela decídua. (Fig. 4e). Material selecionado: Parque Municipal de Mucugê, próximo ao restaurante, $12^{\circ} 18^{\prime}$ 'S, $40^{\circ} 29^{\prime} \mathrm{W}$, 8.I.2005, fl. e fr., J. Costa \& CA.B.N Costa 829 (HUEFS).

Microlicia comparilis é endêmica da Chapada Diamantina (Santos \& Silva 2005), com registro para os municípios de Mucugê, Rio de Contas e Lençóis, ocorrendo geralmente em campos rupestres, em altitudes entre 1.000-1.500 m. Coletada com flores e frutos de janeiro a março. Segundo Wurdack (1984), M. comparilis se assemelha a $M$. minima Markgr., também encontrada em Mucugê, por ambas apresentarem flores magentas e estames amarelos. Contudo, M. comparilis apresenta ramos, folhas e hipanto densamente recobertos por tricomas setosos, lâminas foliares que medem 3-4 × 1-1,5 mm e flores pediceladas. Já em M. minima, os ramos, as folhas e o hipanto apresentam somente glândulas esféricas, as lâminas medem ca. 1,5 ×0,5 mm e as flores são sésseis.

2.3. Microlicia fasciculata Mart. ex Naudin, Ann. Sci. Nat., Bot. sér. 3, 3: 180. 1845.

Arbusto 0,5-1 m alt., cespitoso; ramos, folhas, hipanto e sépalas densamente recobertos por tricomas setosos, ca. 1 mm compr., e glândulas esféricas, douradas; ramos jovens quadrangulares, os mais velhos cilíndricos, afilos na base. Folhas subsésseis, ascendentes, imbricadas, discolores; pecíolo ca. 0,5 mm compr.; lâmina 5-6,5 × 2-3,5 $\mathrm{mm}$, elíptica a oval, ápice agudo, aristado, arista ca. $1 \mathrm{~mm}$ compr., margem crenada, glabra, base truncada, uninérvea. Flores solitárias, terminais; pedicelo ca. $1 \mathrm{~mm}$ compr. Hipanto $2-4 \times 2-2,5$ $\mathrm{mm}$, campanulado ou cilíndrico, 10-costado. Cálice com sépalas 1,5-2 mm compr., deltoides, ápice agudo, aristado, arista 0,5-1 mm compr. Pétalas $6,5-7,5 \times 5-6 \mathrm{~mm}$, alvas, obovais ou raramente oblongas, ápice agudo ou arredondado, geralmente terminado em uma seta, ca. $0,5 \mathrm{~mm}$ compr. Estames 10, dimorfos, os antessépalos com filete 3,5-5 mm compr., róseo, antera ca. 2,5 mm compr., amarela, oblonga, poliesporangiada, rostro ca. 0,5 mm compr., conectivo prolongado 3-4,5 mm compr., apêndice 1-2,5 mm compr., rosado, ápice agudo, os antepétalos com filete 3,5-4 mm compr., róseo, antera ca. $2 \mathrm{~mm}$ compr., amarela, oblonga, poliesporangiada, rostro ca. $1 \mathrm{~mm}$ compr., conectivo prolongado 1,5-2 mm compr., apêndice ca. $0,5 \mathrm{~mm}$ compr., amarelo, ápice truncado. Ovário
2-2,5 × ca. 1,5 mm, oval a oblongo, 3-locular; estilete 5-5,5 mm compr., rosado. Cápsula 4-5 $\times 2,5-3 \mathrm{~mm}$, oval ou globosa, 3-valvar, columela decídua. (Fig. 3i,j).

Material selecionado: Trilha para o Capa Bode, próximo ao Hotel Alpina, 12'9'50''S, 41'3'20'W, 1165 m, 20.VII.2010, fl. e fr., N. Roque 2871 (ALCB).

Microlicia fasciculata ocorre nos estados da Bahia, Goiás, Mato Grosso do Sul, Minas Gerais, São Paulo e no Distrito Federal. Em Mucugê ocorre em campo sujo e campo rupestre. Coletada com flores e com frutos de julho a outubro.

Diferencia-se das demais espécies de flores alvas que ocorrem em Mucugê por apresentar ramos, folhas, hipanto e sépalas densamente recobertos por tricomas setosos, folhas subsésseis e ápice das pétalas geralmente terminado em uma seta com ca. 0,5 mm compr.

\subsection{Microlicia giuliettiana A.B.Martins \&} Almeda, Novon 11: 3. 2001.

Arbusto ca. 1,8 m alt.; ramos jovens quadrangulares, glabros, mais velhos cilíndricos, afilos na base. Folhas sésseis ou subsésseis, ascendentes, imbricadas, concolores; pecíolo ausente ou ca. 0,5 mm compr.; lâmina 6-9 $\times$ 5-6 mm, oboval ou largamente elíptica, ápice mucronado, terminado em um tricoma glandular pedunculado, ca. $1 \mathrm{~mm}$ compr., margem serreada, ciliado-glandulosa, tricomas glandulares pedunculados, ca. $1 \mathrm{~mm}$ compr., base cuneada, ambas as faces recobertas por glândulas esféricas, 1 par de nervuras acródromas basais. Flores solitárias, terminais; pedicelo ca. 1,5 mm compr. Hipanto ca. 2,5 × 2,5 mm, campanulado, 10-costado, glabro. Cálice com sépalas ca. $4 \mathrm{~mm}$ compr., triangulares, ápice agudo, terminado em um tricoma glandular pedunculado, ca. $1 \mathrm{~mm}$ compr., recobertas por tricomas glandulares pedunculados, ca. $1 \mathrm{~mm}$ compr. Pétalas 10-12 × 6,5-8 mm, magentas, obovais, face abaxial com uma faixa vermelha em um dos lados, ápice agudo ou arredondado, glabro. Estames 10, dimorfos, os antessépalos com filete 4,5-5 mm compr., magenta, antera 3-3,5 mm compr., magenta, oblonga, tetraesporangiada, rostro ca. 0,5 mm compr., conectivo prolongado ca. $4 \mathrm{~mm}$ compr., apêndice ca. $2 \mathrm{~mm}$ compr., amarelo, ápice truncado, os antepétalos com filete 4-4,5 $\mathrm{mm}$ compr., magenta, antera ca. 2,5 mm compr., amarela, oblonga, tetraesporangiada, rostro ca. 0,3 mm compr., conectivo prolongado $2-2,5 \mathrm{~mm}$ compr., magenta, apêndice 0,5-1 mm compr., amarelo, ápice truncado. Ovário ca. 2,5 × 1,5 mm, 

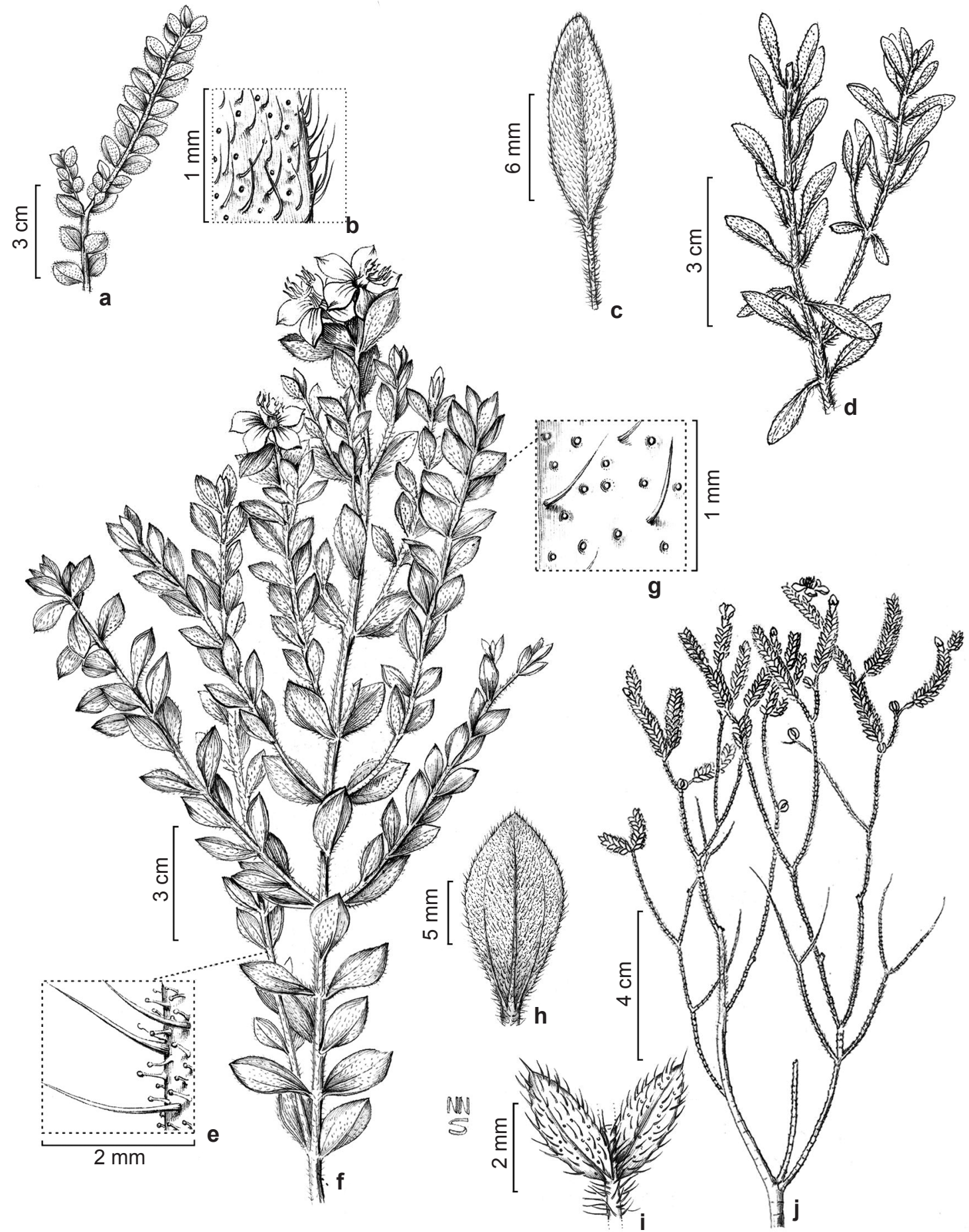

Figura 3 - a,b. Microlicia baccharoides - a. ramo estéril; b. detalhe dos tricomas da face adaxial da folha. c,d. Microlicia leucopetala - c. folha, face adaxial; d. ramo estéril. e-h. Microlicia hirta - e. detalhe dos tricomas setosos dos ramos; f. ramo florífero; g. detalhe dos tricomas setosos das folhas; h. folha, face abaxial. i,j. Microlicia fasciculata - i. par de folhas; j. ramo fértil. (a,b. M.L. Guedes 17152; c,d. A.K.A. Santos et al. 4; e-h. L. Pataro et al. 62; i,j. N. Roque 2871).

Figure 3 - a,b. Microlicia baccharoides - a. sterile branch; b. detail of trichomes of leaf adaxial surface. c,d. Microlicia leucopetala - c. leaf, adaxial surface; d. sterile branch. e-h. Microlicia hirta - e. detail of branch pale trichomes; f. flowering branch; g. detail of leaf abaxial pale trichomes; h. leaf abaxial surface. i,j. Microlicia fasciculata - i. pair of leaves; j. fertile branch. (a,b. M.L. Guedes 17152; c,d. A.K.A. Santos et al. 4; e-h. Pataro et al. 62; i,j. N. Roque 2871). 
piriforme, 3-locular; estilete ca. $7 \mathrm{~mm}$ compr., magenta. Cápsula ca. $4 \times 2 \mathrm{~mm}$, oval, 3-valvar, columela decídua. (Fig. $5 \mathrm{~g}$ ).

Material selecionado: Trilha para o Córrego de Pedra, 12.59'57', S, 41 23'51'W, 974 m, 22.V.2011, fl. e fr, $L$. Pataro \& F.S.E. Santo 36 (HUEFS).

Microlicia giuliettiana é endêmica da Chapada Diamantina, nos municípios de Abaíra, Érico Cardoso, Lençóis, Mucugê, Palmeiras, Piatã e Rio de Contas, onde ocorre em campos rupestres, em altitudes superiores a $900 \mathrm{~m}$ e inferiores a 1.900 m (Almeda \& Martins 2001). Encontrada com flores de janeiro a agosto e com frutos de maio a novembro.

Segundo Almeda \& Martins (2001), um bom caráter diagnóstico para esta espécie é a presença de uma faixa vermelha em um dos lados da face abaxial de cada pétala, dando uma coloração vermelho-escuro aos botões florais. Outros caracteres diagnósticos são as folhas obovais a largamente elípticas de margem serreada, ciliado-glandulosa e com tricomas glandulares pedunculados. Microlicia giuliettiana é similar a $M$. pulchra pelas folhas de margem ciliado-glandulosa e sépalas recobertas por tricomas glandulares pedunculados com ca. $1 \mathrm{~mm}$ compr. Contudo, $M$. pulchra apresenta lâminas foliares glabras, maiores (10,5-12 × 4-5 mm vs. 6-9 ×5-6 mm), pétalas com um tricoma glandular pedunculado no ápice ( $v S$. glabro), estilete maior (14-16 $\mathrm{mm} v s$. ca. $7 \mathrm{~mm}$ ) e columela persistente (vs. decídua).

2.5. Microlicia hirta Pataro \& R.Romero, Kew Bulletin 68(2): 285-286. 2013.

Arbusto ca. 1,5 m alt., cespitoso; ramos, folhas e sépalas recobertos por tricomas setosos, 1-2 mm compr., tricomas glandulares pedunculados ca. 0,2 mm compr. e por glândulas esféricas, dourados; ramos folhosos ao longo do comprimento. Folhas pecioladas, ascendentes, concolores; pecíolo ca. 2 mm compr.; lâmina 16-18,5 × 8,5-9,5 mm, elíptica a levemente oboval, ápice agudo, terminado em uma seta, ca. $1 \mathrm{~mm}$ compr., margem crenada, ciliada, base levemente atenuada, 1(-2) par de nervuras acródromas basais. Flores solitárias, terminais; pedicelo ca. 0,5 mm compr. Hipanto 3-4 × 3-4 mm, campanulado, liso, tricomas glandulares pedunculados, ca. 0,2 mm compr., e tricomas setosos esparsos, ca. $1 \mathrm{~mm}$ compr. Cálice com sépalas 6-6,5 mm compr., lineares, ápice acuminado, terminado em uma seta, 0,5-1 mm compr., margem glandulosa, tricomas glandulares pedunculados, ca. 0,2 mm compr. Pétalas 11-12,5×
5,5-7 mm, obovais, alvas, ápice assimetricamente agudo ou acuminado. Estames 10, dimorfos, amarelos, os antessépalos com filete 4,5-5 $\mathrm{mm}$ compr., antera 2,5-3,5 mm compr., oval a oblonga, poliesporangiada, rostro ca. 0,5 mm compr., conectivo prolongado 4-5 $\mathrm{mm}$ compr., apêndice 1,5-2 mm compr., ápice truncado, os antepétalos com filete 4-4,5 mm compr., antera 2-3 $\mathrm{mm}$ compr., oval a oblonga, poliesporangiada, rostro ca. 0,2 mm compr., conectivo prolongado 1,5-2 mm compr., apêndice ca. $1 \mathrm{~mm}$ compr., ápice truncado. Ovário 2,5-3 × 1,5-2 mm, oval, 5-locular; estilete 7-8 mm compr., amarelo. Cápsula $6-6,5 \times$ ca. 6 mm compr., globosa, 5-valvar, columela decídua. (Fig. 3e-h).

Material selecionado: Serra da Cascalheira, ca. $10 \mathrm{~km}$ ao N de Mucugê, na estrada para Andaraí, 12 ${ }^{\circ} 56^{\prime} 23^{\prime}$ 'S, 41 ${ }^{\circ} 19^{\prime} 37^{\prime}$ 'W, 1.084 m, 10.X.2010, fl. e fr., L. Pataro et al. 62 (ALCB, HUEFS, HUFU, US).

Microlicia hirta é conhecida até o momento nos municípios de Lençóis e Mucugê, na Chapada Diamantina (Pataro et al. 2013). Ocorre em solo arenoso-pedregoso dos campos rupestres, formando pequenas populações aglomeradas, em altitudes que variam de $1.000-1.400 \mathrm{~m}$. Coletada com flores e frutos em março e de junho a novembro. Facilmente reconhecida pelos ramos, folhas e hipanto densamente recobertos por tricomas setosos e glandulares pedunculados, folhas pecioladas, com um par de nervuras acródromas basais, raro dois, flores alvas e estames sempre amarelos. Além disso, $M$. hirta apresenta sépalas desenvolvidas (6-6,5 mm compr.) e ovário 5-locular. Para mais comentários ver $M$. baccharoides.

2.6. Microlicia intercalycina Pataro \& R.Romero, Kew Bulletin 68(2): 286-288. 2013.

Arbusto 0,3-0,5 m alt., cespitoso; ramos, folhas, hipanto, cálice e sépalas densamente recobertos por glândulas esféricas, douradas; ramos jovens quadrangulares, os mais velhos cilíndricos, afilos na base. Folhas sésseis ou subsésseis, ascendentes, concolores; pecíolo ausente ou ca. 0,5 mm compr.; lâmina 5,5-7 × 1,5-2,5 mm, oval ou elíptica, ápice agudo, terminado em uma seta, ca. 0,3 mm compr., margem crenada, setosociliada, base truncada, uninérvea. Flores solitárias, terminais, sésseis ou com pedicelo até $0,5 \mathrm{~mm}$ compr. Hipanto 3-4 × 2,5-3,5 mm, cilíndrico ou campanulado, liso. Cálice com sépalas 2-2,5 mm compr., triangulares, ápice agudo, terminado em uma seta, 1-1,5 mm compr., avermelhada, com um tricoma simples, às vezes dois, intercalado 

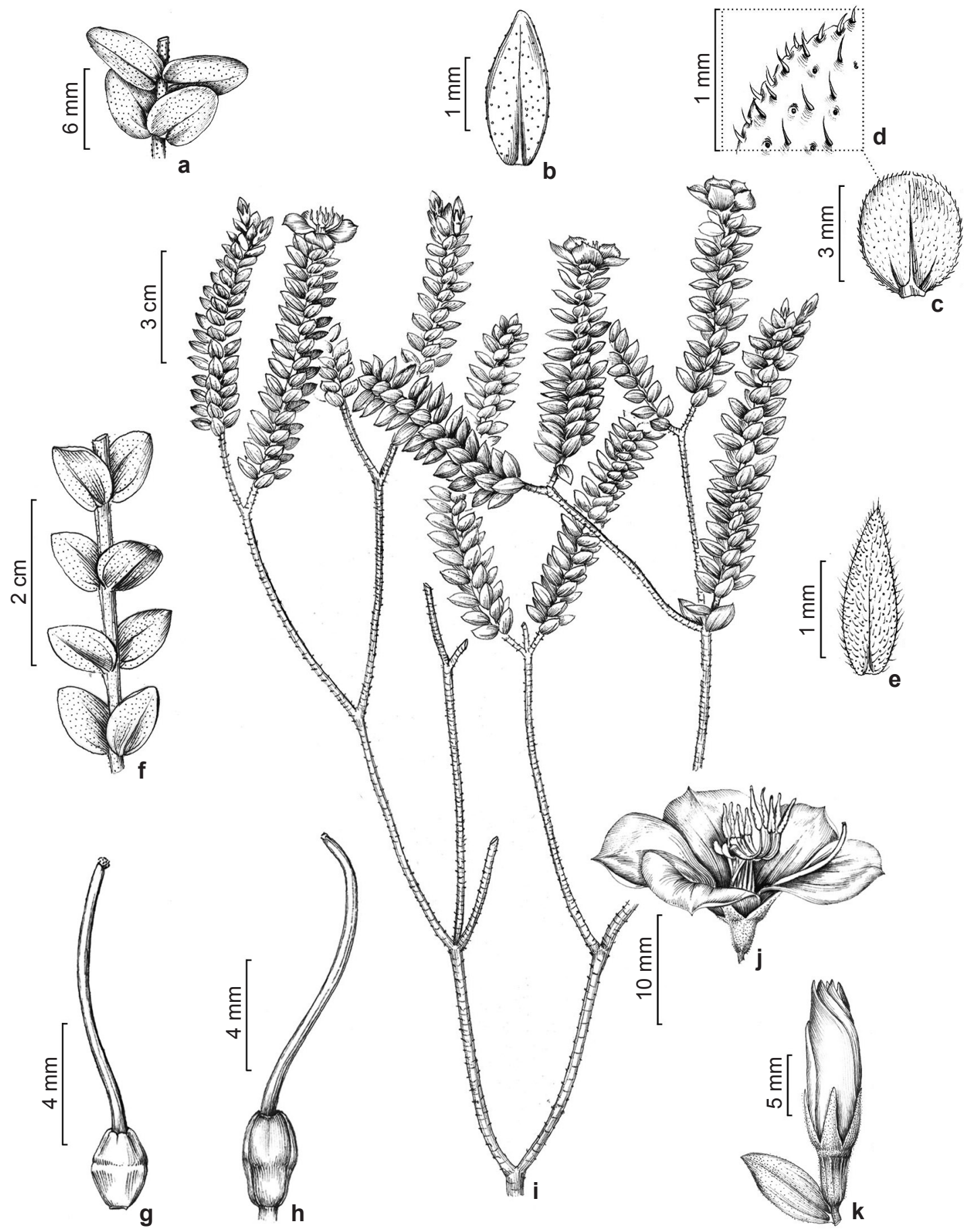

Figura 4-a. Microlicia mucugensis-detalhe do ramo estéril. b. Microliciaminima-folha, faceabaxial.c,d. Microlicia wurdackiana -c. folha, face adaxial; d. detalhe dos tricomas da folha. e. Microlicia comparilis - folha, face abaxial. f,g. Microlicia torrendii -f. detalhe do ramo; g. gineceu. h-k. Microlicia macropetala -h. gineceu; i. ramo florífero; j. flor; k. botão floral. (a. N. Roque 1553; b. V.S. Ferreira etal. 77; c,d. E.L. Borba 1842; e. J. Costa \& C.A.B.NCosta 829; f,g. R.M. Harleyet al. 15904; h-k. L. Pataro et al. 49). Figure 4 - a. Microlicia mucugensis - detail of sterile branch. b. Microlicia minima - leaf, abaxial surface. c,d. Microlicia wurdackiana - c. leaf, adaxial surface; d. detail of leaf trichomes. e. Microlicia comparilis - leaf, abaxial surface. f,g. Microlicia torrendii - f. detail of branch; g. gyneceum. h-k. Microlicia macropetala - h. gyneceum; i. flowering branch; j. flower; k. flower bud. (a. N. Roque 1553; b. V.S. Ferreira et al. 77; c,d. E.L. Borba 1842; e. J. Costa \& C.A.B.N Costa 829; f,g. R.M. Harley et al. 15904; h-k. L. Pataro et al. 49). 
com as sépalas. Pétalas $8-8,5 \times$ ca. $5 \mathrm{~mm}$, amarelas, obovais, ápice assimetricamente agudo ou acuminado. Estames 10, dimorfos, amarelos, exceto pelas anteras, os antessépalos com filete 3-3,5 mm compr., antera 3-3,5 mm compr., amarela ou alaranjada, oval ou oblonga, poliesporangiada, rostro ca. 0,5 mm compr., conectivo prolongado 2-2,5 mm compr., apêndice 0,5-1 mm compr., ápice bilobado ou trilobado, os antepétalos com filete 2,5-3 mm compr., antera ca. 2,5 mm compr., amarela ou alaranjada, oblonga, poliesporangiada, rostro ca. 0,3 mm compr., conectivo prolongado 1-1,5 mm compr., apêndice ca. 0,5 mm compr., ápice trilobado. Ovário 2-2,5 × 1-1,5 mm, oval, 3-locular; estilete 7,5-8 mm compr., amarelo. Cápsula 4-5 × 3-4 mm, oval ou elíptica, 3-valvar, columela decídua. (Fig. 6e-h).

Material selecionado: Antes do Beco do Paty, $12^{\circ} 46^{\prime} 10^{\prime} \mathrm{S}, 41^{\circ} 31^{\prime} 58^{\prime \prime} \mathrm{W}, 1024 \mathrm{~m}, 12 . \mathrm{I} .2011$, fl. e fr., L. Pataro \& H.A. Ogasawara 48 (ALCB, HUEFS; HUFU, US).

Microlicia intercalycina é conhecida até o momento apenas para o entorno do povoado de Guiné, antes do acesso à Serra do Esbarrancado, em cerrado, a $1.100 \mathrm{~m}$ de altitude. Coletada com flores e frutos nos meses de janeiro, março, abril e agosto. Microlicia intercalycina diferencia-se das demais espécies de Microlicia de flores amarelas por apresentar o seguinte conjunto de caracteres: folhas sésseis ou subsésseis, lâmina foliar de margem crenada, setoso-ciliada e uninérvea e cálice com tricoma simples entre as sépalas. Esta espécie tem flores similares às de Microlicia sp. 1, mas difere principalmente pelas folhas com margem crenada e setoso-ciliada ( $v s$. inteira ou levemente crenada), uninérveas ( $v s .1$ par de nervuras acródromas basais) e tricoma simples intercalado com as sépalas (vs. desprovido de tricomas). Microlicia intercalycina se assemelha vegetativamente a M. longisepala Wurdack, contudo, esta última apresenta ramos e folhas recobertos por tricomas setosos e hipanto, cálice e sépalas densamente recobertos por tricomas setosos, além de flores róseas ou magentas.

2.7. Microlicia leucopetala Wurdack, Phytologia 53(2): 127-128. 1983.

Arbusto 1,5-2 $\mathrm{m}$ alt.; ramos, folhas, hipanto, cálice e sépalas densamente recobertos por tricomas setosos, avermelhados, ca. $1 \mathrm{~mm}$ compr., e por glândulas esféricas, douradas; ramos jovens quadrangulares, os mais velhos cilíndricos, glabros, afilos na base. Folhas pecioladas, ascendentes, concolores; pecíolo 2-3(-5) mm compr.; lâmina 2,5-6(-10) × 1-4(-7) mm, elíptica, estreito-elíptica ou oblanceolada, ápice obtuso ou arredondado, margem inteira, glabra, base atenuada, 1 par de nervuras acródromas basais. Flores solitárias, terminais; pedicelo ca. $2 \mathrm{~mm}$ compr. Hipanto 3,5-4 × 2-2,5 mm, campanulado, 10-estriado. Cálice com sépalas 4-5 mm compr., lineares, ápice agudo. Pétalas 8,5-9 × 4-5 mm, alvas, obovais, às vezes oblongas, ápice arredondado, obtuso ou acuminado. Estames 10, dimorfos, amarelos passando a avermelhados, os antessépalos com filete ca. 5,5 mm compr., antera 2-2,5 mm compr., oval, poliesporangiada, rostro ca. 0,2 mm compr., conectivo prolongado ca. 4,5 mm compr., apêndice ca. $2 \mathrm{~mm}$ compr., ápice bilobado, os antepétalos com filete 4-5 mm compr., antera ca. $2 \mathrm{~mm}$ compr., oblonga, poliesporangiada, rostro ca. $0,2 \mathrm{~mm}$ compr., conectivo prolongado 1,5-2 mm compr., apêndice 0,5-1 mm compr., ápice truncado. Ovário 1,5-2 × ca. 1,5 mm, oboval, 3-locular; estilete 6-7 mm compr., amarelo. Cápsula ca. $3 \times 3 \mathrm{~mm}$, globosa, 3-valvar, columela decídua. (Fig. 3c,d).

Material selecionado: Área em frente ao Cemitério Bizantino, $13^{\circ} 0$ '23' 'S, 41 22 '33', W, $1.020 \mathrm{~m}$, 26.VIII.2001, fl. e fr., A.K.A. Santos et al. 4 (HUEFS).

Microlicia leucopetala é endêmica da Chapada Diamantina, com distribuição restrita aos municípios de Andaraí e Mucugê. Ocorre em campos rupestres, em solos arenosos e afloramentos rochosos, em altitudes entre 1.000-1.500 m. Coletada com flores nos meses de setembro a maio e frutos de maio a agosto. Reconhecida pelas flores alvas e tricomas avermelhados distribuídos por toda a planta. Para mais comentários ver $M$. baccharoides.

2.8. Microlicia longisepala Wurdack, Phytologia 53(2): 129-130. 1983.

Arbusto 0,3-0,5 m alt., cespitoso; ramos e folhas recobertos por glândulas esféricas, douradas, e por tricomas setosos, ca. 0,5 mm compr.; ramos jovens quadrangulares, os mais velhos cilíndricos, glabros, afilos na base. Folhas pecioladas, ascendentes, discolores; pecíolo ca. $1 \mathrm{~mm}$ compr.; lâmina 10-12 × 4-6 mm, oval ou lanceolada, ápice agudo, terminado em uma seta, ca. 0,5 mm compr., margem serreada, ciliado-setosa, base atenuada, 1(-2) par de nervuras acródromas basais. Flores solitárias, terminais; pedicelo 1-1,5 mm compr. Hipanto, cálice e sépalas densamente recoberto por tricomas setosos, avermelhados, ca. 1,5 mm compr. Hipanto 3-4 × 2,5-4 mm, campanulado, 

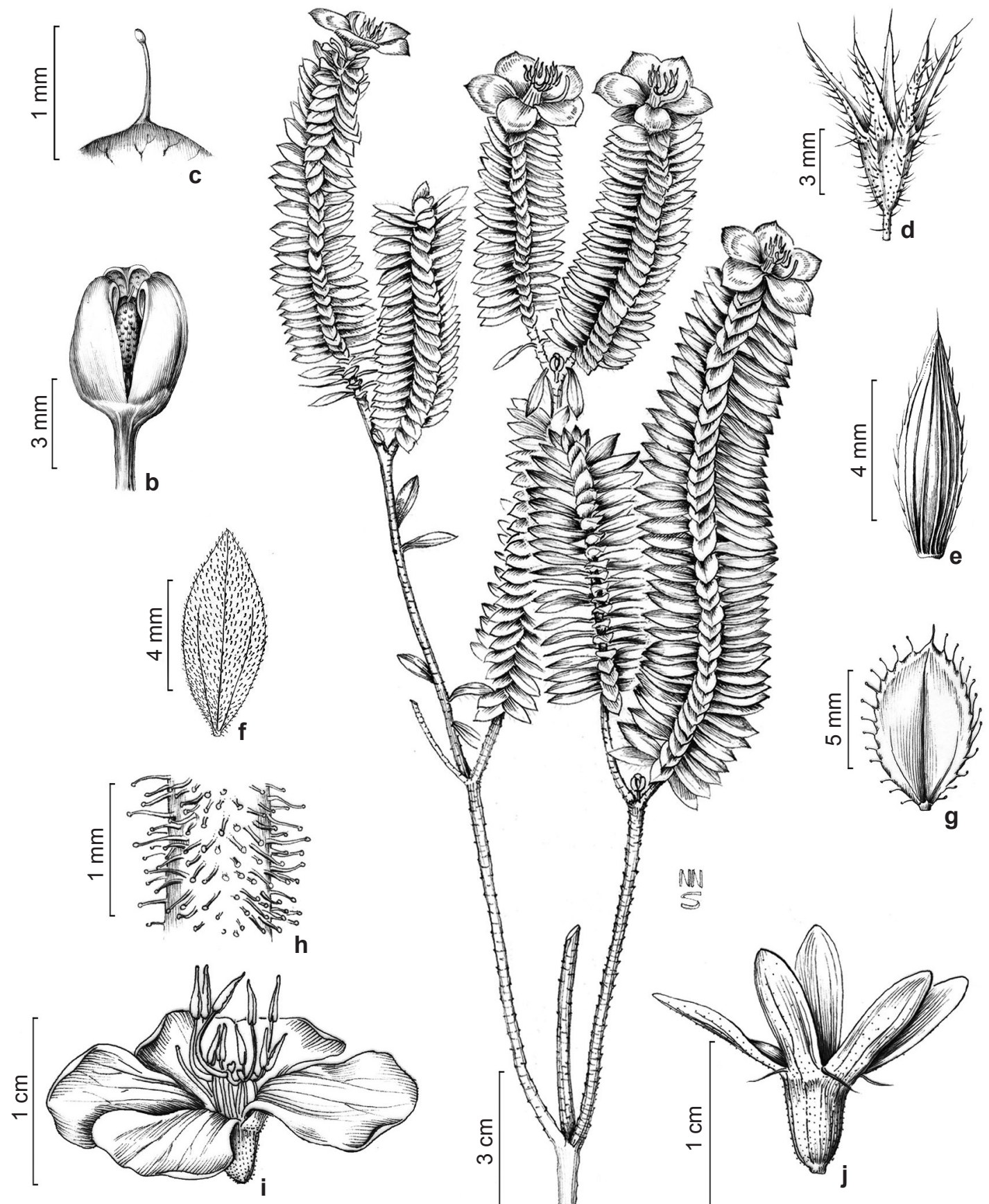

Figura 5-a-c. Microlicia pulchra - a. ramo florífero; b. fruto mostrando columela persistente; c. tricoma glandular pedunculado no ápice da pétala. d. Microlicia longisepala - hipanto e cálice. e. Microlicia viminalis - folha, face abaxial. f. Microlicia neglecta - folha, face abaxial. g. Microlicia giuliettiana - folha, face adaxial. h,i. Microlicia sp. 2 - h. detalhe dos tricomas dos ramos; i. flor. j. Microlicia sp. 4 - hipanto e cálice. (a-c. L. Pataro et al. 43; d. A.A. Conceição \& D. Cardoso 1343; e. G. Hatschbach 48312; f. R. Funch 501; g. L. Pataro \& F.S.E. Santo 36; h,i. A.A. Conceição 858; j. L. Pataro et al. 128).

Figure 5 -a-c. Microlicia pulchra-a. flowering branch; b. fruit showing the persistent columella; c. petal showing pedunculate glandular trichome. d. Microlicia longisepala - hypanthium and calyx. e. Microlicia viminalis - leaf, abaxial surface. f. Microlicia neglecta - leaf, abaxial surface. g. Microlicia giuliettiana - leaf, adaxial surface. h,i. Microlicia sp. 2 - h. detail of branch trichomes; i. flower. j. Microlicia sp. 4 - hypanthium and calyx. (a-c. L. Pataro et al. 43; d. A.A. Conceição \& D. Cardoso 1343; e. G. Hatschbach 48312; f. R. Funch 501; g. L. Pataro \& F.S.E. Santo 36; h,i. A.A. Conceição 858; j. L. Pataro et al. 128). 
verde passando a avermelhado, 10-estriado. Cálice com sépalas ca. $6 \mathrm{~mm}$ compr., estreito-triangulares, ápice agudo, terminado em uma seta, ca. 1,5 mm compr. Pétalas ca. $15 \times 9 \mathrm{~mm}$, róseas, obovais, raro oblongas, ápice agudo ou assimetricamente acuminado. Estames 10, dimorfos, os antessépalos com filete ca. $6 \mathrm{~mm}$ compr., róseo, antera 4-4,5 mm compr., rósea, oval ou oblonga, poliesporangiada, rostro ca. 0,5 mm compr., conectivo prolongado ca. $7 \mathrm{~mm}$ compr., róseo, apêndice ca. 1,5 mm compr., amarelo, ápice trilobado, os antepétalos com filete ca. 5,5 mm compr., róseo, antera ca. $3 \mathrm{~mm}$ compr., rósea, oval ou oblonga, poliesporangiada, rostro ca. $0,3 \mathrm{~mm}$ compr., conectivo prolongado ca. 2,5 $\mathrm{mm}$ compr., róseo, apêndice ca. $1 \mathrm{~mm}$ compr., amarelo, ápice truncado. Ovário 2,5-3 × 1,5-2 $\mathrm{mm}$, globoso, 3-locular; estilete ca. $11 \mathrm{~mm}$ compr., róseo. Cápsula ca. $4 \times 3,5 \mathrm{~mm}$, globosa, 3-valvar, columela decídua. (Fig. 5d).

Material selecionado: Base da Serra do Esbarrancado, $12^{\circ} 45^{\prime} \mathrm{S}, 41^{\circ} 30^{\prime} \mathrm{W}, 1.200 \mathrm{~m}, 16 . \mathrm{IV} .2005$, fl. e fr., $A . A$. Conceição \& D. Cardoso 1343 (HUEFS).

Microlicia longisepala é endêmica da Chapada Diamantina, ocorrendo em campo rupestre e cerrado dos municípios de Mucugê e Delfino, em altitudes que variam de 1.000-1.300 m. Coletada com flores de janeiro a agosto e com frutos de fevereiro a setembro. Reconhecida pelos tricomas setosos distribuídos nos ramos e folhas, hipanto densamente recoberto por tricomas setosos, pétalas róseas e sépalas longas, que atingem o dobro do comprimento do hipanto, terminadas em uma seta com aproximadamente 1,5 $\mathrm{mm}$ de comprimento.

2.9. Microlicia lutea Markgr., Notizbl. Bot. Gart. Berlin-Dahlem 10: 46. 1927.

Arbusto 0,3-1 m alt., cespitoso; ramos, folhas, hipanto, cálice e sépalas densamente recobertos por glândulas esféricas, douradas; ramos jovens quadrangulares, os mais velhos subcilíndricos, glabros, afilos na base. Folhas sésseis ou subsésseis, ascendentes, concolores; pecíolo ausente ou ca. 0,5 mm compr.; lâmina 2,5-4,5 × 1,5-2,5 mm, elíptica a oval, ápice agudo, geralmente aristado, arista, ca. 0,5 mm compr., margem levemente revoluta, inteira, glabra, base cuneada, uninérvea. Flores solitárias, terminais, sésseis ou com pedicelo até $0,5 \mathrm{~mm}$ compr. Hipanto 2,5-4 × ca. $2 \mathrm{~mm}$, campanulado, 10-estriado. Cálice com sépalas ca. $1 \mathrm{~mm}$ compr., triangulares, ápice agudo. Pétalas 4,5-5,5 × 3-3,5 mm, amarelas, obovais, ápice obtuso ou arredondado. Estames
10, dimorfos, amarelos, os antessépalos com filete 2,5-3 mm compr., antera 2-2,5 mm compr., oval a oblonga, poliesporangiada, rostro ca. $0,2 \mathrm{~mm}$ compr., conectivo prolongado 1,5-2 mm compr., apêndice 0,5-1 $\mathrm{mm}$ compr., ápice obtuso, os antepétalos com filete 2,5-3 mm compr., antera ca. $2 \mathrm{~mm}$ compr., oblonga, poliesporangiada, rostro $0,1-0,2 \mathrm{~mm}$ compr., conectivo prolongado $1-1,5 \mathrm{~mm}$ compr., apêndice $0,2-0,5 \mathrm{~mm}$ compr., ápice truncado. Ovário 1-2,5 × 1-1,5 mm, oval, 3-locular; estilete 7,5-8 mm compr., amarelo. Cápsula 3-4 × ca. $3 \mathrm{~mm}$, elíptica, 3-valvar, columela decídua. (Fig. 6i,j).

Material selecionado: Trilha para a Cachoeira do Córrego de Pedra, 130'1"'S, 4123'29' W, $941 \mathrm{~m}$, 22.V.2010, fl. e fr., L. Pataro \& F.S.E. Santo 40 (HUFES).

Microlicia lutea é endêmica da Chapada Diamantina, nos municípios de Abaíra, Mucugê, Piatã, Rio de Contas e Seabra. Ocorre em campos rupestres, afloramentos rochosos ou solos arenosos associados a áreas alagadas, em altitudes que variam de 1.000-1.800 m. Coletada com flores de dezembro a junho e com frutos de junho a dezembro. Em Mucugê, além de M. lutea, encontramos espécimes que se enquadram na circunscrição de $M$. parvula (Markgr.) Koschnitzke \& A.B.Martins. Ambas são muito próximas por apresentarem folhas ovais ou elípticas, sésseis a subsésseis, recobertas em ambas as faces por glândulas esféricas, douradas, uninérveas e flores sésseis ou com pedicelo curto, pétalas e estames amarelos. Contudo, as folhas de M. lutea são bem características por apresentarem margem foliar levemente revoluta e ápice aristado, o que não é observado em M. parvula.

2.10. Microlicia macropetala Pataro \& R.Romero, Kew Bulletin 68(2): 288-290. 2013.

Arbusto ca. 1,5 m alt., cespitoso; ramos, folhas, hipanto e sépalas recobertos por glândulas esféricas, douradas, e tricomas setosos, ca. 0,5 mm compr., apenas entorno das cicatrizes foliares; ramos jovens quadrangulares, os mais velhos cilíndricos, folhosos ao longo do comprimento. Folhas pecioladas, ascendentes, discolores; pecíolo 0,6-1 mm compr.; lâmina 9-10 × 6-7 mm, oval ou largo-elíptica, ápice agudo, margem inteira ou crenada, glabra, base cuneada, 1 par de nervuras acródromas basais. Flores solitárias, terminais; pedicelo 0,5-1 mm compr. Hipanto 4,5-6 × 2,5-3 $\mathrm{mm}$, cilíndrico, 10-costado. Cálice com sépalas 4,5-5 mm compr., triangulares, ápice agudo. Pétalas 20-22,5 × 14-15,5 mm, róseas, obovais, 


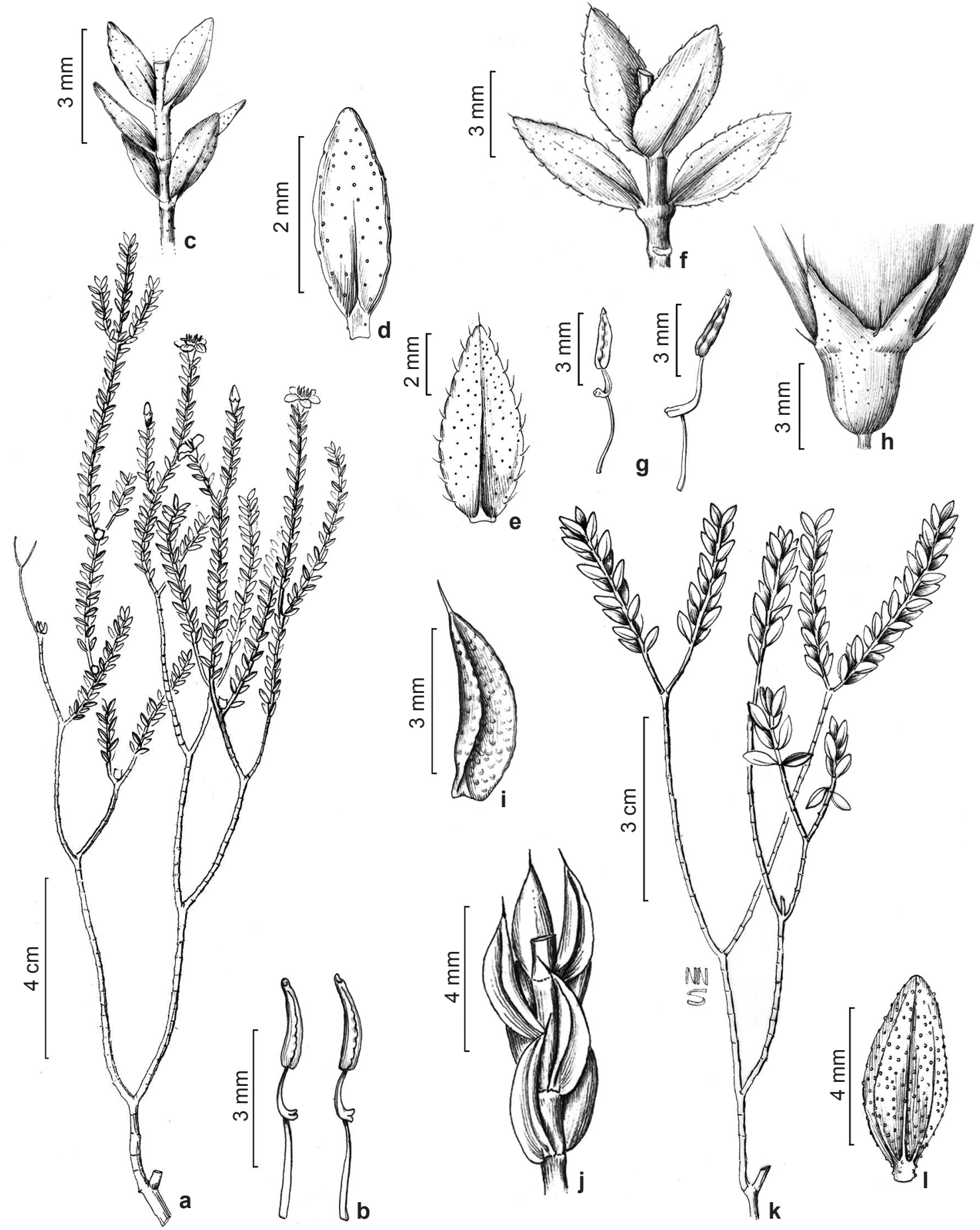

Figura 6-a-d. Microlicia parvula - a. ramo florífero; b. estames isomorfos; c. detalhe do ramo; d. folha, face adaxial. e-h. Microlicia intercalycina - e. folha, face abaxial; f. detalhe do ramo; g. estames antessépalos (direita) e antepétalos (esquerda); h. detalhe do hipanto e cálice. i,j. Microlicia lutea -i. folha; j. detalhe do ramo. k,1. Microlicia sp. 1-k. ramo estéril; 1. folha, face abaxial. (a-d. A.A. Conceição \& D. Cardoso 1342; e-h. L. Pataro 48; i,j. L. Pataro \& F.S.E. Santo 40; k,1. L. Pataro \& H.A. Ogasawara 109). Figure 6-a-d. Microlicia parvula - a. flowering branch; b. isomorphic stamens; c. detail of branch; d. leaf, adaxial surface. e-h. Microlicia intercalycina - e. leaf, abaxial surface; f. detail of branch; g. large (right) and small (left) stamen; h. detail of hypanthium and calyx. i,j. Microlicia lutea - i. folha; j. detail of branch. k,1. Microlicia sp. 1 - k. sterile branch; 1. leaf, abaxial surface. (a-d. A.A. Conceição \& D. Cardoso 1342; e-h. L. Pataro 48; i,j. L. Pataro \& F.S.E. Santo 40; k,1. L. Pataro \& H.A. Ogasawara 109). 
ápice assimetricamente acuminado ou apiculado. Estames 10, dimorfos, os antessépalos com filete 6,5-7 mm compr., róseo, antera 4,5-5 $\mathrm{mm}$ compr., rósea, oval, poliesporangiada, rostro ca. $0,5 \mathrm{~mm}$ compr., conectivo prolongado 6-7 $\mathrm{mm}$ compr., róseo, apêndice $2-2,5 \mathrm{~mm}$ compr., amarelo, ápice trilobado, os antepétalos com filetes 5-6 mm compr., róseo, antera 3,5-4 mm compr., amarela, oval ou oblonga, poliesporangiada, rostro ca. $1 \mathrm{~mm}$ compr., conectivo prolongado $2-2,5 \mathrm{~mm}$ compr., amarelo, apêndice 1-2 mm compr., amarelo, ápice truncado, raro bilobado. Ovário 3-4 × 2-3 mm, oboval, 3-locular; estilete 11-12,5 mm compr., róseo. Cápsula ca. $3 \times 2,5 \mathrm{~mm}$, oval, 3-valvar, columela decídua. (Fig. 4h-k).

Material selecionado: Serra do Esbarrancado, 1246'11"S, 41'29'34"W, 1.335 m, 17.VIII.2010, fl. e fr., L. Pataro et al. 49 (ALCB, HUEFS).

Microlicia macropetala é conhecida até o momento apenas dos campos rupestres da Serra do Esbarrancado, em Mucugê, em altitudes entre $1.200-1.400 \mathrm{~m}$. Coletada com flores e frutos nos meses de fevereiro, junho e agosto. Reconhecida pelas folhas pecioladas, recobertas somente por glândulas esféricas, douradas, hipanto cilíndrico, 10-costado, sépalas triangulares, com 4-4,5 mm de comprimento, flores róseas e, principalmente, pelas pétalas grandes (20-22,5 × 14-15,5 mm). Ademais, apresenta tricomas setosos, com ca. $0,5 \mathrm{~mm}$ de comprimento, somente entorno das cicatrizes foliares. Assemelha-se a $M$. torrendii Brade pelas glândulas esféricas, douradas, distribuídas por toda a planta, folhas elípticas a ovais e flores róseas. No entanto, M. macropetala apresenta tricomas setosos entorno das cicatrizes foliares ( $v s$. glabros), lâminas foliares maiores $(9-10 \times 6-7 \mathrm{~mm} v s .6-7 \times 4,5-5,5$ $\mathrm{mm})$, pétalas maiores $(20-22,5 \times 14-15,5 \mathrm{vs}$. ca. 12 $\times 7 \mathrm{~mm}$ ) e estilete maiores (11-12,5 vs. 7-8 mm).

2.11. Microlicia minima Markgr., Notizbl. Bot. Gart. Berlin-Dahlem 10: 46. 1927.

Arbusto ca. $50 \mathrm{~cm}$ alt., cespitoso; ramos, folhas, hipanto, cálice e sépalas recobertos por glândulas esféricas, douradas; ramos jovens quadrangulares, os mais velhos cilíndricos e glabros, afilos na base. Folhas sésseis, ascendentes, concolores; lâmina ca. 1,5×1 mm, oval ou elíptica, ápice agudo, margem plana, inteira, glabra, base truncada, uninérvea. Flores solitárias, terminais, sésseis. Hipanto ca. $3 \times 2,5 \mathrm{~mm}$, campanulado, liso. Cálice com sépalas $1-1,5 \mathrm{~mm}$ compr., estreito-triangulares, ápice agudo, terminado em uma seta, ca. 0,3 mm compr. Pétalas $4-4,5 \times$ ca.
2,5 mm, magentas, obovais ou oblongas, ápice acuminado. Estames 10, isomorfos, amarelos; filete $2-2,5 \mathrm{~mm}$ compr., antera ca. $2 \mathrm{~mm}$ compr., oval, poliesporangiada, rostro ca. $0,1 \mathrm{~mm}$ compr., conectivo prolongado ca. $1,5 \mathrm{~mm}$ compr., apêndice ca. 0,5 mm compr., ápice bilobado. Ovário ca. $1 \times$ $1 \mathrm{~mm}$, globoso, 3-locular; estilete ca. $5 \mathrm{~mm}$ compr., amarelo. Cápsula 1,5-2 × ca. $1 \mathrm{~mm}$, elíptica, 3-valvar, columela decídua. (Fig. 4b).

Material selecionado: $13^{\circ} 0^{\prime}$ 'S, $41^{\circ} 23^{\prime \prime} \mathrm{W}, 16 . X I I .2005$, fl., V.S. Ferreira et al. 77 (HUEFS).

Material adicional: Rio de Contas, estrada para Cachoeira do Fraga, ca. $100 \mathrm{~m}$ das margens da cachoeira, 1313'57'S, 4149'37'"W, 930 m, 1.IV.2004, fl. e fr., J.R. Pirani et al. 5378 (SPF).

Microlicia minima é endêmica dos campos rupestres da Chapada Diamantina, ocorrendo nos municípios de Rio de Contas e Mucugê, em atitudes entre 900-1.200 m. Facilmente reconhecida pelas lâminas foliares diminutas, com ca. 1,5 × 1 $\mathrm{mm}$, flores sésseis e pétalas magentas. Para mais comentários ver M. comparilis.

2.12. Microlicia mucugensis (Wurdack) Almeda \& A.B.Martins, Novon 11: 4. 2001.

Arbusto 1,4-2 m alt., cespitoso; ramos densamente recobertos por tricomas glandulares pedunculados, ca. 0,2 mm compr.; ramos jovens cilíndricos, os mais velhos quadrangulares, glabros, afilos na base. Folhas sésseis, ascendentes, concolores; lâmina 6,5-8 × 4-6 mm, orbicular ou elíptica, ápice arredondado, margem inteira, não calosa, glabra, base cordada, 2 pares de nervuras acródromas basais, ambas as faces recobertas por tricomas glandulares curto-pedunculados, ca. 0,2 mm compr. Flores solitárias, terminais; pedicelo 1-1,5 mm compr. Hipanto, cálice e sépalas recobertos por glândulas esféricas, douradas; hipanto 4-5,5 × 2,5-4 mm, campanulado, 10-estriado. Cálice com sépalas ca. $4 \mathrm{~mm}$ compr., estreito-triangulares, ápice aristado, arista, ca. 0,2 $\mathrm{mm}$ compr. Pétalas 10-12 × 7-8 mm, magentas, obovais, ápice agudo ou arredondado. Estames 10, dimorfos, amarelos, os antessépalos com filete 5-5,5 mm compr., antera 4-4,5 $\mathrm{mm}$ compr., oblonga, tetraesporangiada, rostro ca. $0,5 \mathrm{~mm}$ compr., conectivo prolongado ca. $5 \mathrm{~mm}$ compr., apêndice 2-2,5 $\mathrm{mm}$ compr., ápice obtuso, os antepétalos com filete 4-5 mm compr., antera ca. 3 $\mathrm{mm}$ compr., oblonga, tetraesporangiada, rostro ca. $0,3 \mathrm{~mm}$ compr., conectivo prolongado $2-2,5 \mathrm{~mm}$ compr., apêndice ca. $1 \mathrm{~mm}$ compr., ápice truncado. Ovário 2,5-3 × 1,5-2 mm, globoso, 5-locular; 
estilete ca. 9 mm compr., amarelo. Cápsula ca. 4 $\times$ 3,5 mm, globosa, 5-valvar, columela decídua. (Fig. 4a).

Material selecionado: Parque Municipal de Mucugê, trilha para a Cachoeira das Andorinhas, $13^{\circ} 1^{\prime} \mathrm{S}, 41^{\circ} 20^{\prime} \mathrm{W}$, 19.V.2007, fl. e fr., N. Roque 1553 (ALCB).

Microlicia mucugensis é endêmica da Chapada Diamantina, ocorrendo nos campos rupestres dos municípios de Andaraí, Mucugê e Jussiape, entre 900-1.200 m de altitude (Almeda \& Martins 2001). Coletada com flores em janeiro, maio e de julho a setembro e com frutos de maio a setembro. Inicialmente, Wurdack (1988) descreveu esta espécie no gênero Lavoisiera, pela presença do ovário 5-locular. Contudo, Almeda \& Martins (2001) a transferiram para Microlicia, devido aos frutos com deiscência apical, ovário súpero e columela decídua, caracteres utilizados na circunscrição deste gênero. Assemelha-se a M. noblickii (Wurdack) A.B.Martins \& Almeda pelos ramos recobertos por tricomas glandulares pedunculados, folhas sésseis, flores magentas, estames amarelos e ovário 5-locular. No entanto, M. mucugensis apresenta lâminas foliares menores (6,5-8 × 4-6 mm vs. 14-16 ×9-12,5 mm), sépalas menores (ca. $4 \mathrm{~mm}$ vs. 8-8,5 mm), prolongamento do conectivo dos estames antessépalos menores (ca. 5,5 $\mathrm{mm}$ vs. 7-8 $\mathrm{mm}$ ) e anteras tetraesporangiadas (vs. poliesporangiadas).

2.13. Microlicia neglecta Cogn. in Mart., Eichler \& Urban, Fl. bras. 14(3): 118. 1883.

Arbusto 0,5-1,5 $\mathrm{m}$ alt.; ramos, folhas, hipanto, cálice e sépalas densamente recobertos por tricomas glandulares pedunculados, ca. 0,5 mm compr., caducos ou não; ramos jovens quadrangulares, os mais velhos cilíndricos, glabros, afilos na base. Folhas pecioladas, ascendentes, concolores; pecíolo ca. $1 \mathrm{~mm}$ compr.; lâmina 14-15,5 × 5-5,5 mm, oblonga ou elíptica, ápice arredondado, agudo ou apiculado, margem crenada, glabra, base atenuada, 1 par de nervuras acródromas basais. Flores solitárias, terminais; pedicelo 0,5-1 mm compr. Hipanto ca. $5 \times 2,5-3$ mm, campanulado, 10-estriado. Cálice com sépalas 3,5-4 mm compr., lineares, ápice arredondado. Pétalas 14-15 × 8,5-10 mm, magentas, obovais, ápice assimetricamente apiculado ou acuminado. Estames 10, dimorfos, amarelos, os antessépalos com filete ca. 4,5-6 mm compr., antera ca. $5 \mathrm{~mm}$ compr., oblonga, poliesporangiada, rostro ca. $1 \mathrm{~mm}$ compr., conectivo prolongado 8-9,5 mm compr., apêndice 2-2,5 $\mathrm{mm}$ compr., ápice trilobado, os antepétalos com filete 4-4,5 mm compr., antera ca. $4 \mathrm{~mm}$ compr., oblonga, poliesporangiada, rostro ca. $5 \mathrm{~mm}$ compr., conectivo prolongado $2-2,5 \mathrm{~mm}$ compr., apêndice 1-1,5 mm compr., ápice truncado. Ovário 3-3,5 × 2-2,5 mm, elíptico, 3-locular; estilete 13-14 mm compr., amarelo. Cápsula 7-9 $\times$ 5-6 mm, elíptica, 3-valvar, columela decídua. (Fig. 5f).

Material selecionado: Capão do Correio, 13\%7'8"S, 41'23'13"W, 13.I.2005, fl., R. Funch 501 (HUEFS, SPF). Material adicional: Barra da Estiva, Face norte da Serra do Ouro, $7 \mathrm{~km}$ ao sul de Barra da Estiva, na estrada para Ituaçu, $13^{\circ} 40^{\prime} \mathrm{S}, 4^{\circ} 20^{\prime} \mathrm{W}, 1.150 \mathrm{~m}, 30 . \mathrm{I} .1974$, fl. e fr., R.M. Harley et al. 15699 (CEPEC, NY, UEC, US).

Microlicia neglecta é conhecida, até o momento, nos municípios de Barra da Estiva, Ibicoara e Mucugê, na Chapada Diamantina, onde ocorre em campos rupestres. Coletada com flores e frutos nos meses de janeiro e setembro. Reconhecida pelos tricomas glandulares pedunculados, com ca. $0,5 \mathrm{~mm}$ de comprimento, distribuídos pelos ramos, folhas, hipanto e sépalas, flores de pétalas magentas e estames amarelos. Microlicia neglecta é similar a Microlicia sp. 2 pelos ramos com tricomas glandulares pedunculados, flores magentas e estames amarelos. Contudo, Microlicia sp. 2 apresenta lâminas foliares menores (7-9 × 3-5 mm vs. $14-15,5 \times 5-5,5 \mathrm{~mm})$, prolongamento do conectivo dos estames antessépalos menores (ca. $5 \mathrm{~mm}$ vs. 8-9,5 mm), anteras tetraesporangiadas (vs. poliesporangiadas) e ovário 4-locular ( $v s$. 3-locular).

2.14. Microlicia noblickii (Wurdack) A.B.Martins \& Almeda, Novon 11(1): 4. 2001.

Arbusto ca. 1,5 m alt., cespitoso; ramos densamente recobertos por tricomas glandulares pedunculados, ca. 0,5 mm compr.; ramos jovens quadrangulares, os mais velhos cilíndricos, glabros, folhosos ao longo do comprimento. Folhas sésseis, ascendentes, concolores; lâmina 14-16 × 9-12,5 $\mathrm{mm}$, elíptica, ápice mucronado, margem inteira, não calosa, glabra, base levemente cordada, ambas as faces recobertas por glândulas esféricas, douradas, 1 par de nervuras acródromas basais. Flores solitárias, terminais; pedicelo ca. 1,5 $\mathrm{mm}$ compr. Hipanto, cálice e sépalas recobertos por glândulas esféricas, douradas; hipanto campanulado, 4-5 $\times 3-3,5 \mathrm{~mm}$, liso. Cálice com sépalas $8-8,5 \mathrm{~mm}$ compr., triangulares, ápice agudo. Pétalas ca. $19 \times$ $12 \mathrm{~mm}$, magentas, obovais, ápice assimetricamente agudo, apiculado ou mucronado. Estames 10, dimorfos, amarelos, os antessépalos com filete ca. $8 \mathrm{~mm}$ compr., antera ca. $5 \mathrm{~mm}$ compr., oval, 
poliesporangiada, rostro ca. $1 \mathrm{~mm}$ compr., conectivo prolongado 7-8 $\mathrm{mm}$ compr., apêndice ca. $3 \mathrm{~mm}$ compr., ápice trilobado, os antepétalos com filete 6-7 mm compr., antera ca. 3,5 mm compr., oblonga, poliesporangiada, rostro ca. 0,5 $\mathrm{mm}$ compr., conectivo prolongado ca. $3 \mathrm{~mm}$ compr., apêndice ca. $2 \mathrm{~mm}$ compr., ápice truncado. Ovário ca. 3,5 × 2,5 mm, elíptico, 5-locular; estilete 7-8 $\mathrm{mm}$ compr., amarelo. Cápsula 7-9 × 5-6 mm, elíptica, 5-valvar, columela decídua. (Fig. 2d).

Material selecionado: Gerais do Rio Preto, Trilha Esbarrancado-Mirante, 8.I.2012, fl., H.A. Ogasawara $\& M$. Alves 175 (ALCB).

Material adicional: Palmeiras, Pai Inácio, 12²7'3'S, 4128'17'”W, 21.XI.1994, fl. e fr., Melo et al. 1197 (ALCB).

Microlicia noblickii era conhecida apenas das redondezas do Morro do Pai Inácio, entre os municípios de Lençóis e Palmeiras (Almeda \& Martins 2001), mas coletas recentes feitas em Mucugê apontam sua ocorrência nesse município. Coletada com flores de outubro a janeiro e com frutos em junho. Reconhecida pelas folhas sésseis, de base levemente cordada, pétalas magentas de ápice agudo, apiculado ou mucronado, anteras poliesporangiadas e ovário 5-locular. Para mais comentários ver M. mucugensis.

2.15. Microlicia parvula (Markgr.) Koschnitzke \& A.B.Martins, Novon 17(4): 474. 2007.

Arbusto 0,3-1,5 m alt., cespitoso; ramos, folhas, hipanto, cálice e sépalas densamente recobertos por glândulas esféricas, douradas; ramos jovens quadrangulares, os mais velhos cilíndricos, glabros, afilos na base. Folhas sésseis ou subsésseis, ascendentes, concolores; pecíolo ausente ou ca. 0,2 mm lâmina 2,5-3 × 1-1,5 mm, oval ou elíptica, ápice agudo, margem plana, crenada, glabra, base cuneada, uninérvea. Flores solitárias, terminais, sésseis ou subsésseis, pedicelo até $0,5 \mathrm{~mm}$ compr. Hipanto 3-3,5 × 1,5-2 mm, campanulado, 10-estriado. Cálice com sépalas triangulares, ca. $1 \mathrm{~mm}$ compr. Pétalas ca. $5 \times 2-3 \mathrm{~mm}$, amarelas, obovais, ápice arredondado ou assimetricamente acuminado. Estames 10, iso a subisofomorfos, amarelos; filete ca. $2 \mathrm{~mm}$ compr., antera 1,5-2 mm compr., oval ou oblonga, poliesporangiada, rostro ca. 0,2 mm compr., conectivo prolongado 1,5-2 mm compr., apêndice pouco desenvolvido, ca. 0,2 mm compr., ápice bilobado. Ovário 1,5-2 × ca. 1 $\mathrm{mm}$, oboval, 3-locular; estilete 5,5-6 mm compr., amarelo. Cápsula ca. $2 \times 1,5 \mathrm{~mm}$, elíptica, 3-valvar, columela decídua. (Fig. 6a-d).
Material selecionado: Base da Serra do Esbarrancado, $12^{\circ} 45^{\prime} \mathrm{S}, 4^{\circ} 30^{\prime} \mathrm{W}, 1.200 \mathrm{~m}, 16 . \mathrm{IV} .2005$, fl. e fr., $A . A$. Conceição \& D. Cardoso 1342 (HUEFS).

Microlicia parvula é endêmica da Chapada Diamantina, ocorrendo nos campos rupestres dos municípios de Abaíra, Água Quente, Mucugê, Rio de Contas, Lençóis, Piatã e Seabra, em altitudes que variam de 900-1.400 m. Coletada com flores e frutos praticamente em todos meses do ano. Conforme mencionado anteriormente, esta espécie é próxima de $M$. lutea, conforme discutido nos comentários desta espécie.

2.16. Microlicia pinheiroi Wurdack, Phytologia 53(2): 121-122. 1983.

Arbusto ca. 1,5 m alt., cespitoso; ramos, folhas, hipanto, cálice e sépalas densamente recobertos por glândulas esféricas, douradas; ramos jovens quadrangulares, também com tricomas setosos esparsos, os mais velhos cilíndricos, glabros, afilos na base. Folhas pecioladas, ascendentes, concolores; pecíolo 0,6-1 mm compr.; lâmina 5,5-7 × 1,5-2 mm, lanceoladooblonga ou elíptico-oblonga, ápice agudo, margem levemente revoluta, inteira, glabra, base cuneada, uninérvea. Flores solitárias, terminais; pedicelo ca. 0,5 mm compr. Hipanto ca. $3 \times 2,5 \mathrm{~mm}$, campanulado, 10-estriado. Cálice com sépalas 3,5-4 mm compr., triangulares, ápice agudo. Pétalas 8,5-9 ×5-5,5 mm, lilases, obovais, ápice assimetricamente acuminado ou obtuso. Estames 10, dimorfos, amarelos passando a avermelhados, os antessépalos com filete ca. $4 \mathrm{~mm}$ compr., antera ca. $3 \mathrm{~mm}$ compr., oval, poliesporangiada, rostro ca. 0,5 mm compr., conectivo prolongado ca. $4 \mathrm{~mm}$ compr., apêndice 1-1,5 mm compr., ápice bilobado, os antepétalos com filete ca. 3,5 mm compr., antera ca. 2,5 mm compr., oblonga, poliesporangiada, rostro ca. 0,3 $\mathrm{mm}$ compr., conectivo prolongado $1-1,5 \mathrm{~mm}$ compr., apêndice ca. 0,5 mm compr., ápice bilobado. Ovário ca. 2,5 $\times$ 1-1,5 mm, oboval, 3-locular; estilete 7,5-8 mm compr., amarelo, passando a avermelhado. Cápsula ca. $3 \times 2,5 \mathrm{~mm}$, oval, 3-valvar, columela decídua (Fig. 2e).

Material selecionado: Serra do Sincorá, $10 \mathrm{~km}$ ao norte de Mucugê, na rodovia para Andaraí, 1256'S, 41 ${ }^{\circ} 20^{\prime} \mathrm{W}$, 1.050 m, 8.II.1974, fl., R.M. Harley et al. 16120 (CEPEC; US); Serra do Esbarrancado, 12\%45'29' S, 41³0'21'”, 1.355 m, 24.VI.2011, fr., L. Pataro et al. 123 (HUEFS).

Microlicia pinheiroi é endêmica da Chapada Diamantina, ocorrendo nos campos rupestres dos municípios de Andaraí, Mucugê e Palmeiras. 
Coletada com flores e com frutos nos meses de fevereiro a junho. Reconhecida pelas folhas com margem foliar levemente revoluta, flores lilases e estames amarelos passando a avermelhados com a maturidade. Vegetativamente se assemelha a Microlicia sp. 3, que apresenta folhas sésseis (vs. pecioladas), flores alvas de ápice rosado (vs. lilases), ápice arredondado ou agudo ( $v s$. assimetricamente acuminado ou obtuso) e estilete maior (ca. $11 \mathrm{~mm}$ vs. 7,5-8 mm).

2.17. Microlicia pulchra Pataro \& R.Romero, Kew Bulletin 68(2): 290-293. 2013.

Arbusto ca. 1,5 m alt., cespitoso; ramos cilíndricos, tricomas glandulares pedunculados, ca. 0,2 mm compr., na axila das folhas, cicatrizes foliares evidentes, afilos na base. Folhas sésseis ou subsésseis, acentuadamente imbricadas, concolores; pecíolo ausente ou ca. 0,5 mm compr.; lâmina 10,5-12 × 4-5 mm, elíptica ou oblanceolada, ápice agudo, terminado em um tricoma glandular pedunculado, ca. $1 \mathrm{~mm}$ compr., margem serreada, ciliado-glandulosa, tricomas glandulares pedunculados, ca. $1 \mathrm{~mm}$ compr., base cuneada, ambas as faces glabras, 1 par de nervuras acródromas basais, ambas as faces glabras. Flores solitárias, terminais; pedicelo 2,5-3 mm compr. Hipanto 2,5-3 × 2,5-3 mm, campanulado, 10-costado, glabro. Cálice com sépalas 3,5-5 mm compr., triangulares, ápice agudo, terminado em uma seta com ca. $1 \mathrm{~mm}$ compr., recobertas por tricomas glandulares pedunculados, ca. $1 \mathrm{~mm}$ compr. Pétalas 15-16,5 × 7-8 mm, magentas, oblongas, ápice agudo ou arredondado, terminado em um tricoma glandular pedunculado, ca. $1 \mathrm{~mm}$ compr. Estames 10, dimorfos, os antessépalos com filete 6-7 mm compr., magenta, antera 4,5-5 $\mathrm{mm}$ compr., enegrecida, oblonga, poliesporangiada, rostro ca. 0,5 mm compr., conectivo prolongado 4,5-6 mm compr., magenta, apêndice 1-2 mm compr., ápice trilobado, amarelo, os antepétalos com filete 6-6,5 mm compr., magenta, antera 3,5-4 $\mathrm{mm}$ compr., vinácea, oblonga, poliesporangiada, rostro ca. 0,3 mm compr., amarelo, conectivo prolongado 2-2,5 mm compr., amarelo, apêndice 0,5-1 mm compr., amarelo, ápice truncado, às vezes bilobado. Ovário ca. $3 \times 2-2,5 \mathrm{~mm}$, oval ou cilíndrico, 3-locular; estilete 14-16 mm compr., magenta. Cápsula 4-5 × 3-4 mm, oval ou elíptica, 3-valvar, columela persistente. (Fig. 5a-c).

Material selecionado: Serra do Esbarrancado, 12'45'48'S, 41'30'4"'W, 1.325 m, 17.VIII.2010, fl. e fr., L. Pataro et al. 53 (ALCB, HUEFS, HUFU).
Microlicia pulchra é conhecida, até o momento, apenas na Serra do Esbarrancado, ocorrendo em campos rupestres próximos a cursos d'água (Pataro et al. 2013). Coletada com flores e frutos de agosto a novembro. Esta espécie é reconhecida pelas folhas acentuadamente imbricadas, de margem serreada, ciliadoglandulosa, hipanto glabro, sépalas recobertas por tricomas glandulares pedunculados, pétalas magentas, com ápice terminado em um tricoma glandular pedunculado, além da columela persistente. Segundo Almeda \& Martins (2001), o gênero Microlicia é caracterizado por apresentar flores 5-meras, ovário súpero, fruto deiscente do ápice em direção à base e columela decídua. Apesar da columela persistente, M. pulchra apresenta flores 5-meras, ovário livre no interior do hipanto e deiscência da cápsula do ápice em direção à base.

Microlicia pulchra se assemelha a $M$. giuliettiana pelas folhas de margem serreada, ciliado-glandulosa, hipanto glabro, sépalas recobertas por tricomas glandulares pedunculados e flores magenta. Contudo, difere, principalmente, pelo ápice das pétalas com um tricoma glandular pedunculado e columela persistente. Para mais comentários ver $M$. giuliettiana.

2.18. Microlicia torrendii Brade, Arq. Bot. estado de São Paulo 3: 252. 1962.

Arbusto 1-2 m alt., cespitoso; ramos, folhas, hipanto, cálice e sépalas densamente recobertos por glândulas esféricas, douradas; ramos jovens quadrangulares, os mais velhos cilíndricos, glabros, folhosos ao longo do comprimento. Folhas sésseis ou subsésseis, ascendentes, discolores; pecíolo ausente ou ca. 0,3 mm compr.; lâmina 6-7,5 × 4,5-5,5 mm, oval, elíptica ou oboval, ápice obtuso ou arredondado, margem inteira, não calosa, glabra, base cuneada, 1 par de nervuras acródromas basais. Flores solitárias, terminais; pedicelo ca. 0,5 mm compr. Hipanto ca. $4 \times$ $3 \mathrm{~mm}$, campanulado, 10-costado. Cálice com sépalas ca. $3 \mathrm{~mm}$, triangulares, ápice agudo a curto-aristado, arista ca. 0,2 mm compr. Pétalas ca. $12 \times 7 \mathrm{~mm}$, lilases ou róseas, obovais, ápice arredondado ou assimetricamente acuminado. Estames 10, dimorfos, os antessépalos com filete ca. $6 \mathrm{~mm}$ compr., róseo, antera ca. $4 \mathrm{~mm}$ compr., amarela, oval ou oblonga, poliesporangiada, rostro ca. 0,5 mm compr., conectivo prolongado 5-5,5 $\mathrm{mm}$ compr., róseo, apêndice ca. 2 mm compr., amarelo, ápice trilobado, os antepétalos com filete 4-5 $\mathrm{mm}$ compr., róseo, antera 2,5-3 $\mathrm{mm}$ 
compr., amarela, oblonga, poliesporangiada, rostro 0,5-1 mm compr., conectivo prolongado 1,5-2 $\mathrm{mm}$ compr., róseo, apêndice ca. $1 \mathrm{~mm}$ compr., róseo, ápice truncado. Ovário 1-2,5 × 1-1,5 mm, oval, 3-locular; estilete 7-8 $\mathrm{mm}$ compr., róseo. Cápsula ca. 6,5 × $4 \mathrm{~mm}$, elíptica, 3-valvar, columela decídua. (Fig. 4f,g).

Material selecionado: Rio Cumbuca, ca. $3 \mathrm{~km}$ ou sul de Mucugê, rodovia para Cascavel, $13^{\circ} 1^{\prime} \mathrm{S}, 4^{\circ} 21^{\prime} \mathrm{W}, 850$ m, 4.II.1974, fl. R.M. Harley et al. 15904 (CEPEC, NY, US); $3 \mathrm{~km}$ ao sul de Mucugê, na estrada para Jussiape, $13^{\circ} 0^{\prime}$ S, $41^{\circ} 24^{\prime}$ W, 26.VII.1979, fr., S.A. Mori et al. 12588 (CEPEC).

Microlicia torrendii é endêmica dos campos rupestres da Chapada Diamantina, ocorrendo nos municípios de Andaraí, Mucugê, Palmeiras, Rio de Contas e Lençóis. Coletada com flores entre setembro e maio, com pico de floração entre os meses de outubro a janeiro e com frutos de maio a julho. Assemelha-se a $M$. macropetala pelos ramos recobertos por tricomas glandulares pedunculados, folhas elípticas, com um par de nervuras acródromas basais, hipanto 10-costado e flores róseas. Para mais comentários ver $M$. macropetala.

2.19. Microlicia viminalis (DC.) Triana, Trans. Linn. Soc. Bot. 28: 28. 1873.

Subarbusto 0,3-1 malt.; ramos quadrangulares, glabros ou com tricomas glandulares pedunculados, afilos na base. Folhas sésseis, ascendentes, rígidas, imbricadas, discolores; lâmina 5,5-7 × 1,5-2,5 $\mathrm{mm}$, elíptica ou estreitamente oval, ápice agudo, com uma seta terminal, margem inteira, calosa, com tricomas glandulares pedunculados, ca. 0,2 mm compr., base atenuada, ambas as faces glabrescentes, as mais jovens com tricomas glandulares pedunculados, 3 ou 4 pares de nervuras sub-paralelódromas, evidentes em ambas as faces. Flores solitárias, terminais; pedicelo ca. $1 \mathrm{~mm}$ compr. Hipanto 4-5 × 2-3 mm, campanulado, 10-estriado, recoberto por tricomas glandulares pedunculados. Cálice com sépalas ca. $5 \times 1,5 \mathrm{~mm}$, triangulares, ápice com uma seta ca. $0,5 \mathrm{~mm}$ compr., tricomas glandulares pedunculados, ca. 0,2 $\mathrm{mm}$ compr. Pétalas ca. $12 \times 7 \mathrm{~mm}$, magentas, obovais, ápice agudo. Estames 10, dimorfos, os antessépalos com filete ca. $6 \mathrm{~mm}$ compr., róseo, antera ca. 5 mm compr., amarela, oblonga, tetraesporangiada, rostro ca. $1 \mathrm{~mm}$ compr., conectivo prolongado 5-6 mm compr., róseo, apêndice ca. 1,5 mm compr., amarelo, ápice truncado, os antepétalos com filete ca. $5 \mathrm{~mm}$ compr., róseo, antera ca. 4 mm compr., amarela, oblonga, tetraesporangiada, rostro ca. $1 \mathrm{~mm}$ compr., conectivo prolongado ca. $1 \mathrm{~mm}$ compr., róseo, apêndice ca. 0,5 mm compr., amarelo, ápice obtuso. Ovário 1-2,5 × 1-1,5 $\mathrm{mm}$, oval, 3-locular; estilete ca. $9 \mathrm{~mm}$ compr., róseo. Cápsula 5-6 × 3-4 mm, globosa, 3-valvar, columela decídua (Fig. 5e).

Material selecionado: Dois Córregos, ao longo do rio, 16.IX.1984, fl., G. Hatschbach 48312 (CEPEC, HRB, SPF); Estrada Palmeiras-Guiné, ca. 20 km de Guiné, $12^{\circ} 36^{\prime} 51^{\prime \prime S}, 41^{\circ} 34^{\prime} 28^{\prime \prime W}, 1.200$ m, 14.V.1999, fr., $R$. Romero et al. 5769 (UEC).

Microlicia viminalis distribui-se nos estados da Bahia, Goiás, Minas Gerais e no Distrito Federal (Romero 2003). Coletada com flores de junho a setembro e com frutos em maio. Esta é a única espécie de Microlicia com ocorrência em Mucugê, cujas folhas são sésseis, fortemente imbricadas, rígidas, de ápice agudo, apiculado, com 3-4 pares de nervuras subparalelódromas, e as anteras tetraesporangiadas.

2.20. Microlicia wurdackiana Almeda \& A.B.Martins, Kew Bulletin 67: 467. 2012.

Arbusto ca. 1,5 m alt.; ramos, folhas, hipanto, cálice e sépalas recobertos por glândulas esféricas, douradas e tricomas setosos, ca. 0,5 mm compr.; ramos jovens quadrangulares, os mais velhos cilíndricos, afilos na base. Folhas pecioladas, ascendentes, imbricadas, concolores; pecíolo 0,5-1 mm compr.; lâmina 5-7 × 3-4,5 mm, oboval ou largo-elíptica, ápice arredondado, margem crenada, glabra, base cuneada, 1 par de nervuras acródromas basais. Flores solitárias, terminais; pedicelo ca. 0,5 mm compr. Hipanto 3-3,5 × 2,5-3 mm, campanulado, liso. Cálice com sépalas lanceoladas, 1,5-2 mm compr., ápice curto-aristado, arista ca. 0,5 mm compr. Pétalas 7-7,5 × 5,5-6 mm, róseas, obovais, ápice arredondado ou assimetricamente acuminado. Estames 10, dimorfos, amarelos passando a avermelhados, os antessépalos com filete 4,5-5 mm compr., antera ca. $3 \mathrm{~mm}$ compr., oval, poliesporangiada, rostro ca. $0,5 \mathrm{~mm}$ compr., conectivo prolongado 4,5-5 mm compr., apêndice ca. 1,5 mm compr., ápice trilobado, os antepétalos com filete 4-4,5 mm compr., antera 2-2,5 mm compr., oval ou oblonga, poliesporangiada, rostro 0,3-5 mm compr., conectivo prolongado ca. $2 \mathrm{~mm}$ compr., apêndice ca. $1 \mathrm{~mm}$ compr., ápice trilobado. Ovário ca. 2,5 × 1,5 mm, oval, 3-locular; estilete 6-7 mm compr., amarelo, passando a avermelhado. Cápsula ca. $4 \times 3 \mathrm{~mm}$, oval, 3-valvar, columela decídua. (Fig. 4c-d). 
Material selecionado: Serra do Gobira, 13\%4'38'S, 41'23'31'W, 4.VIII.2004, fl. e fr., E.L. Borba et al. 1842 (HUEFS).

Microlicia wurdackiana tem sido coletada nos municípios de Mucugê e Palmeiras, em campos rupestres, entre 1.000-1.400 m de altitude, onde provavelmente é endêmica. Coletada com flores nos meses de maio e outubro e com frutos de dezembro a maio. Reconhecida pelo seguinte conjunto de caracteres: ramos, folhas, hipanto, cálice e sépalas recobertos por glândulas esféricas, douradas, e por tricomas setosos, com ca. 0,5 $\mathrm{mm}$ compr., folhas obovais ou largo-elípticas, pétalas róseas e estames amarelos passando a avermelhados com a maturidade.

\subsection{Microlicia sp. 1}

Arbusto 1-1,5 m alt.; ramos, folhas, hipanto e cálice recobertos por glândulas esféricas, douradas; ramos jovens quadrangulares, recobertos por tricomas estrigosos, esparsos, os mais velhos cilíndricos, glabros, afilos na base. Folhas subsésseis, ascendentes, imbricadas, concolores; pecíolo ausente ou ca. 0,5 mm compr.; lâmina 7,5-8,5 × 3,5-4 mm, elíptica, ápice agudo ou arredondado, margem inteira ou crenulada, glabra, base cuneada, 1 par de nervuras acródromas basais. Flores solitárias, terminais; pedicelo $1-1,5 \mathrm{~mm}$ compr. Hipanto ca. $4 \times 2,5 \mathrm{~mm}$, campanulado, 10-costado. Cálice com sépalas ca. $2 \mathrm{~mm}$ compr., triangulares, ápice agudo, aristado, arista ca. 0,2 $\mathrm{mm}$ compr. Pétalas ca. $8 \times 5 \mathrm{~mm}$, amarelas, obovais, ápice acuminado. Estames 10, dimorfos, amarelos, os antessépalos com filete 4-4,5 mm compr., antera ca. $3 \mathrm{~mm}$ compr., oval, poliesporangiada, rostro $0,5-1 \mathrm{~mm}$ compr., conectivo prolongado $2-2,5 \mathrm{~mm}$ compr., apêndice 1,5-2 mm compr., ápice truncado, os antepétalos com filete 3,5-4 mm compr., antera 2,5-3 mm compr. oblonga, poliesporangiada, rostro ca. $0,5 \mathrm{~mm}$ compr., conectivo prolongado ca. $1 \mathrm{~mm}$ compr., apêndice ca. $1 \mathrm{~mm}$ compr., ápice truncado. Ovário $2-2,5 \times$ ca. $1,5 \mathrm{~mm}$, oboval, 3-locular; estilete 10-11 mm compr., amarelo. Cápsula ca. $4 \times 2 \mathrm{~mm}$, elíptica, 3 -valvar, columela decídua. (Fig. 6k,1).

Material selecionado: Córrego de Pedra, 1259'57'S, 41'23'51'W, 980 m, 20.V.2011, fl. e fr, L. Pataro \& H.A. Ogasawara 109 (HUEFS).

Microlicia sp. 1 é conhecida por uma única coleta, às margens do Rio Preto. Coletada com flores e com frutos em maio. O conjunto de caracteres encontrados neste espécime não permite seu posicionamento taxonômico em nenhuma espécie conhecida do gênero. Microlicia sp. 1 diferencia-se das demais espécies de pétalas amarelas pelas folhas subsésseis, com pecíolo medindo ca. $0,5 \mathrm{~mm}$ de comprimento, lâmina foliar com 7,5-8,5 × 3,5-4 mm, de margem inteira ou crenulada e pedicelo floral com 1-1,5 mm de comprimento. Espécie afim de $M$. intercalycina, conforme abordado nos comentários desta espécie.

\subsection{Microlicia sp. 2}

Arbusto 0,5-1,5 $\mathrm{m}$ alt.; ramos, folhas, hipanto, cálice e sépalas densamente recobertos por tricomas glandulares pedunculados, ca. 0,2 $\mathrm{mm}$ compr.; ramos jovens quadrangulares, os mais velhos cilíndricos, afilos na base. Folhas pecioladas, ascendentes, imbricadas, concolores; pecíolo 0,6-1 mm compr.; lâmina 7-9 × 3-5 mm, elíptica, ápice agudo ou arredondado, aristado, arista ca. $0,5 \mathrm{~mm}$ compr., margem inteira ou crenulada, glabra, base cuneada, 1 par de nervuras acródromas basais. Flores solitárias, terminais, sésseis. Hipanto 4-5 × 3-3,5 mm, campanulado, liso. Cálice com sépalas 5-7 mm, triangulares, ápice agudo. Pétalas 17-19 × 10,5-13 mm, magentas, geralmente com a base creme, obovais, ápice arredondado ou agudo. Estames 10, dimorfos, amarelos, os antessépalos com filete 5-6 mm compr., antera 3,5-4 mm compr., oval ou oblonga, tetraesporangiada, rostro ca. $0,5 \mathrm{~mm}$ compr., conectivo prolongado ca. $5 \mathrm{~mm}$ compr., apêndice ca. $2 \mathrm{~mm}$ compr., ápice truncado, raramente agudo, os antepétalos com filete 4-5 mm compr., antera 3,5-4 mm compr., oval ou oblonga, tetraesporangiada, rostro ca. $0,5 \mathrm{~mm}$ compr., conectivo prolongado 1,5-2 $\mathrm{mm}$ compr., apêndice ca. $1 \mathrm{~mm}$ compr., ápice truncado. Ovário 3-4 × 2,5-3 mm, globoso ou oval, 4-locular; estilete ca. $10 \mathrm{~mm}$ compr., amarelo. Cápsula 4,5-5 $\times 3-3,5 \mathrm{~mm}$, elíptica ou oval, 4-valvar, columela decídua. (Fig. 5h,i).

Material selecionado: Serra do Riachão, 29.XII.2004, fl., A.A. Conceição et al. 858 (HUEFS); Trilha para

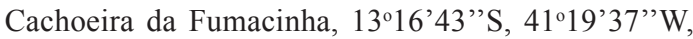
21.V.2011, fr., L. Pataro \& H.A. Ogasawara 114 (HUEFS).

Exemplares aqui indicados como Microlicia sp. 2 foram encontrados em campos rupestres de Mucugê, em altitudes entre 1.000-1.400 $\mathrm{m}$. Coletada com flores de maio a dezembro e com frutos em junho. Os caracteres presentes nos exemplares coletados não permitem o posicionamento taxonômico em nenhuma espécie 
já descrita do gênero. Microlicia sp. 2 diferenciase das demais espécies de Microlicia de Mucugê por apresentar tricomas glandulares pedunculados, com ca. 0,2 $\mathrm{mm}$ comprimento, distribuídos por toda a planta, folhas com pecíolo medindo 0,5-1 mm de comprimento, flores sésseis, pétalas magentas com a base creme, estames amarelos, anteras tetraesporangiadas e ovário 4-locular. Espécie afim de $M$. neglecta, conforme abordado nos comentários desta espécie.

\subsection{Microlicia sp. 3}

Arbusto $0,5-1 \mathrm{~m}$ alt.; ramos jovens, folhas, hipanto, cálice e sépalas recobertos por glândulas esféricas, douradas; ramos jovens quadrangulares, os mais velhos cilíndricos, glabrescentes, afilos na base. Folhas sésseis, ascendentes, concolores; lâmina 5,5-7 × 2-3,5 mm, oval ou elíptica, ápice agudo, margem crenada, glabra, base truncada, uninérvea. Flores solitárias, terminais; pedicelo ca. 0,5 mm compr. Hipanto 4-5 × 2,5-3 mm, campanulado ou cilíndrico, 10-estriado. Cálice com sépalas ca. $3 \mathrm{~mm}$ compr., triangulares, ápice agudo, às vezes terminado em um tricoma glandular pedunculado, ca. $1 \mathrm{~mm}$ compr. Pétalas ca. $12 \times 7 \mathrm{~mm}$, alvas de ápice rosado, obovais, ápice arredondado ou agudo. Estames 10, dimorfos, amarelos, os antessépalos com filete ca. $5 \mathrm{~mm}$ compr., antera ca. $5 \mathrm{~mm}$ compr., oblonga, poliesporangiada, rostro ca. $0,5 \mathrm{~mm}$ compr., conectivo prolongado 3,5-4 mm compr., apêndice 1,5-2 mm compr., ápice agudo, os antepétalos com filete ca. $4 \mathrm{~mm}$ compr., antera ca. $4,5 \mathrm{~mm}$ compr., oblonga, poliesporangiada, rostro ca. $0,3 \mathrm{~mm}$ compr., conectivo prolongado ca. $1,5 \mathrm{~mm}$ compr., apêndice ca. $1 \mathrm{~mm}$ compr., ápice truncado. Ovário 3-3,5 × 2-2,5 mm, oboval, 3-locular; estilete ca. $11 \mathrm{~mm}$ compr., amarelo. Cápsula ca. $5 \times 3,5 \mathrm{~mm}$, elíptica, 3-valvar, columela decídua (Fig. 2f).

Material selecionado: Beco do Paty, 12 $45^{\prime} 24^{\prime \prime} S$, $41^{\circ} 30^{\prime} 43^{\prime}$ 'W, 1.205 m, 24.VI.2011, fl. e fr., L. Pataro et al. 120 (HUEFS).

Assim como Microlicia sp.1, Microlicia sp. 3 também é conhecida por uma única coleta feita em Mucugê, na subida do Beco do Paty, em campo rupestre. Coletada com flores e com frutos no mês de junho. A combinação de caracteres encontrados nessa coleta não permite seu posicionamento taxonômico em nenhuma espécie já descrita no gênero. Possivelmente, trata-se de uma espécie nova e estudos estão sendo conduzidos para o posicionamento da identidade correta deste espécime. Dentre as espécies de pétalas alvas que ocorrem em Mucugê, Microlicia sp. 3 é a única que apresenta ramos jovens, folhas, hipanto e sépalas recobertos somente por glândulas esféricas, douradas, folhas sésseis, ápice das sépalas apresentando um tricoma glandular pedunculado, ápice das pétalas rosado e estames amarelos.

\subsection{Microlicia sp. 4}

Arbusto 1-1,5 m alt.; ramos, folhas, hipanto, cálice e sépalas recobertos por glândulas esféricas, douradas; ramos jovens quadrangulares, os mais velhos cilíndricos, glabros, folhosos ao longo do comprimento. Folhas sésseis ou subsésseis, ascendentes, concolores; pecíolo ausente ou ca. 0,3 mm compr.; lâmina 12,5-15 × 3-4 $\mathrm{mm}$, estreito-elíptica ou oblanceolada, ápice agudo, margem inteira, não calosa, glabra, base truncada, 1 par de nervuras acródromas basais. Flores solitárias, terminais; pedicelo $0,5-1 \mathrm{~mm}$ compr. Hipanto 4,5-5 × 2,5-3 mm, cilíndrico, 10-estriado. Cálice com sépalas ca. $6-8 \mathrm{~mm}$, foliáceas, oblongas, com um tricoma rígido, 1,5-2,5 mm compr., alternissépalo. Pétalas 16-19 $\times$ 9-12 mm, róseas, obovais, ápice agudo ou apiculado. Estames 10, dimorfos, amarelos exceto pelas anteras róseas, os antessépalos com filete 6-6,5 mm compr., antera 4-5 mm compr., oval ou oblonga, poliesporangiada, rostro $0,5-1 \mathrm{~mm}$ compr., conectivo prolongado 6-7 $\mathrm{mm}$ compr., apêndice 2-2,5 mm compr., ápice bilobado, os antepétalos com filete 5-5,5 $\mathrm{mm}$ compr., antera 3,5-4 mm compr., oblonga, poliesporangiada, rostro ca. $0,5 \mathrm{~mm}$ compr., conectivo prolongado ca. $2 \mathrm{~mm}$ compr., apêndice $1-1,5 \mathrm{~mm}$ compr., ápice truncado. Ovário 3,5-5 × 2,5-3 mm, oboval, 3 -locular; estilete ca. $11 \mathrm{~mm}$ compr., rosado. Fruto não observado. (Fig. 5j).

Material selecionado: Beco do Paty, $12^{\circ} 45^{\prime} 24^{\prime \prime}$, $41^{\circ} 30^{\prime} 43^{\prime}$ 'W, 1.205 m, 24.VI.2011, fl., L. Pataro et al. 128 (HUEFS).

Provável espécie nova para o município de Mucugê, Microlicia sp. 4 também é conhecida por uma única coleta feita no Beco do Paty, em campo rupestre, a ca. $1.200 \mathrm{~m}$ de altitude. Coletada somente com flores em agosto. Quando em flor, Microlicia sp. 4 é facilmente reconhecida pelas sépalas foliáceas, longas, com 6-8 $\mathrm{mm}$ de comprimento, e os tricomas rígidos intercalados entre as sépalas, característica que a distingue das demais espécies de Microlicia em Mucugê. Esforços estão sendo feitos para coletar novos espécimes, a fim de complementar a descrição. 
3.1. Trembleya parviflora (D.Don) Cogn. in Mart., Urban \& Eichler, Fl. bras. 14(3): 127. 1883.

Arbusto ou arvoreta 1,5 a $3 \mathrm{~m}$ alt.; ramos jovens quadrangulares, recobertos por tricomas glandulares pedunculados e tricomas setosos, os mais velhos cilíndricos, glabrescentes, folhosos ao longo do comprimento. Folhas pecioladas, verdes, discolores; pecíolo 5-6 mm compr.; lâmina 53-60 × 15-20 mm, elíptica, ápice agudo ou arredondado, margem levemente revoluta, base atenuada, ambas as faces recobertas por glândulas esféricas, douradas, tricomas glandulares pedunculados e tricomas setosos adensados sobre as nervuras, 1 par de nervuras acródromas basais. Dicásios axilares; brácteas $10-11 \times 2-3 \mathrm{~mm}$, ovais; bractéolas ca. $6 \times 3 \mathrm{~mm}$. Flores 5-meras; pedicelo 1,5-2 mm compr. Hipanto $2-2,5 \times$ ca. $2 \mathrm{~mm}$, campanulado, liso, e, como as sépalas, recoberto por glândulas esféricas, douradas; sépalas ca. 1 $\mathrm{mm}$, triangulares, ápice terminado em uma seta curta, ca. 0,2 mm compr. Pétalas 5-6 × 3-4 mm, alvas, algumas vezes de base rósea, obovais, ápice agudo ou arredondado. Estames 10, dimorfos, os antessépalos com filete ca. 3,5 mm compr., róseo, antera ca. 1,5 $\mathrm{mm}$ compr. (incluindo rostro), vinácea, oblonga, tetraesporangiada, rostro ca. 0,5 mm compr., conectivo prolongado ca. 2,5 $\mathrm{mm}$ compr., róseo, apêndice ventral 1-1,2 mm compr., amarelo, ápice bilobado, os antepétalos com filete 2-2,5 $\mathrm{mm}$ compr., róseo, antera ca. $1,5 \mathrm{~mm}$ compr. (incluindo rostro), amarela, oval, tetraesporangiada, rostro ca. $0,3 \mathrm{~mm}$ compr., conectivo prolongado ca. $0,5 \mathrm{~mm}$ compr., róseo, apêndice ventral ca. 0,1 mm compr., róseo, ápice truncado. Ovário ca. $2 \times 1,5 \mathrm{~mm}$, globoso, 3-locular; estilete ca. 2,5 mm compr., alvo. Cápsula ca. $3 \times 2,5 \mathrm{~mm}$, oval, deiscente do ápice para a base, 3-valvar (Fig. 2g).

Material selecionado: Beco do Paty, 1245'24' S, 41'30'43' W, 1.205 m, fl. e fr., L. Pataro et al. 54 (HUEFS).

Trembleya é um gênero endêmico do Brasil, com 12 espécies distribuídas principalmente nos campos rupestres dos estados de Minas Gerais, Goiás, Bahia e São Paulo (BFG 2015). As espécies diferenciam-se por apresentar flores 5-meras formando dicásios, ovário 3-5 locular, intrusões placentárias subpeltadas e frutos deiscentes do ápice em direção à base (Almeda \& Martins 2001; Fritsch et al. 2004).

Trembleya parviflora distribui-se nos estados da Bahia, Espírito Santo, Goiás, Minas
Gerais, Paraná, Rio de Janeiro e São Paulo, em campo rupestre, cerrado e também em bordas de fragmentos de Mata Atlântica (Almeda \& Martins 2001). Coletada com flores e frutos de maio a outubro. Dentre as espécies da tribo Microlicieae que ocorrem em Mucugê, é a única que apresenta inflorescências em dicásios axilares, com brácteas e bractéolas.

\section{Agradecimentos}

Aos curadores dos herbários visitados, especialmente, ao Dr. Pedro Acevedo e ao Dr. Fabian Michelangeli, o auxílio com os materiais de Microlicia nos herbários US e NY, respectivamente; ao Smithsonian Institution, a bolsa Cuatrecasas; a Natanael Nascimento, as ilustrações; ao Dr. José Fernando A. Baumgratz, as valiosas sugestões no manuscrito; à CAPES, a bolsa de Mestrado (LP); e ao CNPq 3051139/20169, a bolsa de Pesquisa (NR).

\section{Referências}

Almeda F \& Martins AB (2001) New combinations and new names in some Brazilian Microlicieae (Melastomataceae), with notes on the delimitation of Lavoisiera, Microlicia and Trembleya. Novon 11: 1-7.

Almeda F \& Martins AB (2012) Microlicia wurdackiana (Melastomataceae: Microlicieae); a new species from Bahia, Brazil. Kew Bulletin 67: 467-470.

Baumgratz JFA, Souza MLR, Woodgyer EM \& Lughadha EMN (1996) Polysporangiate Anthers: Described for the first time in Melastomataceae. Kew Bulletin 51: 133-144.

BFG - The Brazil Flora Group (2015) Growing knowledge: an overview of seed plant diversity in Brazil. Rodriguésia 66: 1085-1113.

Clausing G \& Renner SS (2001) Molecular phylogenetics of Melastomataceae and Memecylaceae: implications for character evolution. American Journal of Botany 88: 486-498.

Cogniaux AC (1883) Microlicieae. In: Martius CFP, Eichler AW \& Urban I (eds.) Flora brasiliensis. Fleischer, Leipzig. Vol. 14, pp. 6-510.

Fritsch PW, Almeda F, Renner SS, Martins AB \& Cruz BC (2004) Phylogeny and classification of the near-endemic Brazilian Tribe Microlicieae (Melastomataceae). American Journal of Botany 91: 1105-1114.

Harley RM \& Simons NA (1986) Florula of Mucugê. Royal Botanical Gardens, Kew. 228p.

Harley RM (1995) Introdução. In: Stannard BL (ed.) Flora of the Pico das Almas, Chapada Diamantina, Bahia, Brasil. Royal Botanical Gardens, Kew, London. Pp. 43-76. 
Koschnitzke C \& Martins AB (2006) Revisão taxonômica de Chaetostoma DC. (Melastomataceae, Microlicieae). Arquivos do Museu Nacional 64: 95-119.

Kriebel R (2011) A synopsis of the genus Poteranthera (Melastomeae: Melastomataceae) with the description of a new, apparently pollinator deceiving species. Brittonia 64: 6-14.

Pataro L, Romero R \& Roque N (2013) Four new species of Microlicia (Melastomataceae) from Chapada Diamantina, Bahia, Brazil. Kew Bulletin 68: 285-293.

Martins E (1997) Revisão taxonômica do gênero Trembleya DC. (Melastomataceae). Tese de Doutorado. Universidade Estadual de Campinas, Campinas. 162p.

Nolasco MC, Lima CCU, Franca-Rocha W \& Rêgo MJM (2008) Aspectos físicos da Serra do Sincorá, Chapada Diamantina. In: Funch LS, Funch RR \& Queiroz LP (eds.) Serra do Sincorá: Chapada Diamantina. Radami, Feira de Santana. 251p.

Radford AE, Dickinson WC, Massey JR \& Bell CR (1986) Vascular plant systematics. Harper \& Row, New York. 498p.

Rapini A, Ribeiro PL, Lambert S \& Pirani JR (2008) A flora dos campos rupestres da Cadeia do Espinhaço. Megadiversidade 4: 16-24.

Renner SS (1990) A revision of Rhynchanthera (Melastomataceae). Nordic Journal of Botany 9: 601-630.

Rocha MJR, Guimarães PJF, Michelangeli F \& Romero $\mathrm{R}$ (2016) Phylogenetic placement and a new circumscription of Poteranthera (Microlicieae; Melastomataceae). Phytotaxa 263: 219-232.

Rodrigues KF (2005)A tribo Microlicieae(Melastomataceae) na Serra do Cabral, Minas Gerais. Dissertação de
Mestrado, Universidade Estadual de Campinas, Campinas. 142p.

Romero R (2003) Revisão taxonômica de Microlicia sect. Chaetostomoides (Melastomataceae). Revista Brasileira de Botânica 26: 429-435.

Romero R (2013) Taxonomic notes in Microlicia (Melastomataceae, Microlicieae). Phytotaxa 110: 48-54.

Romero R \& Castro NM (2014) Microlicia longicalycina (Melastomataceae), a new species from the state of Minas Gerais, Brazil, with notes on leaf anatomy. Systematic Botany 39: 1177-1182.

Romero R \& Woodgyer EM (2014) Rediscovery of two species of Microlicia (Melastomataceae) in Minas Gerais, Brazil. Phytotaxa 173: 41-48.

Romero R, Silva KR \& Simão DG (2015a) Microlicia crassa and M. maculata spp. nov. (Melastomataceae) from Minas Gerais, Brazil: morphology and leaf anatomy. Nordic Journal of Botany 33: 178-185.

Romero R, Silva KR \& Simão DG (2015b) Microlicia cogniauxiana and Microlicia naudiniana (Melastomataceae), two new species from the Espinhaço Range, Brazil. Systematic Botany 2015 40: 1012-1021.

Santos AKA \& Silva TRS (2005)A família Melastomataceae no município de Rio de Contas, Bahia, Brasil. Sitientibus Série Ciências Biológicas 5: 76-92.

Woodgyer EM (2005) Multi-access key and cheklist to the species of Microlicia (Melastomataceae) in Bahia, Brasil. Kew Bulletin 60: 441-448.

Woodgyer EM \& Zappi DC (2009) Two new species of Microlicia D. Don (Melastomataceae) from Bahia, NE Brazil. Kew Bulletin 64: 279-284.

\footnotetext{
Lista de exsicatas

Borba EL 1842 (22). Carvalho-Sobrinho J 303 (10). Conceição AA 858 (24), 1177 (12), 1308 (1), 1342 (17), 1343 (10), 1344 (8), 1390 (7), 1769 (27). Costa J 829 (4). Espírito-Santo FS 180 (19). Ferreira VS 48 (14), 77 (13), 80 (3). França F 4140 (3). Freitas J 536 (3). Funch R 501 (15), 510 (10), 650 (1). Funch LS 179 IMSEAR (10), 2017 (3). Furlan A CFCR 2001 (2), CFCR 2035 (15). Ganev W 837 (14). Giulietti AM 1374 (9), 1934 (14), 14376 (11), CFCR 1553 (2). Guedes ML 17152 (3), 17154 (20). Harley RM 15699 (15), 15904 (20), 16062 (11), 16048 (14), 16094 (9), 16120 (18), 18863 (17), 54066, (3), 55898 (2), PCD 3689 (27). Hatshbach G 47466 (3), 47502 (14), 47971 (20), 48312 (21). Hind N PCD 3657 (17). Hurbath F 100 (3). King LRM 8760 (10). Melo 1197 (16). Menezes NL CFCR 1442 (2). Mori SA 12455 (1), 12551 (2), 12588 (20). Moura LM 26 (3). Noblick LR 2914 (20). Ogasawara HA 175 (16). Oliveira RP 29 (7). Orlandi RP 741 (3). Pataro L 36 (6), 40 (11), 48 (8), 49 (12), 50 (10), 53 (19), 54 (27), 62 (7), 67 (22), 109 (23), 113 (6), 114 (24), 120 (25), 123 (18), 128 (26). Pigozzo CAM 6 (5), 60 (4). Pirani JR 5378 (13). Queiroz LP 1847 (20), 13719 (2). Rodrigues KF 290 (2). Romero R 5769 (21). Roque N 611 (10), 1068 (17), 1553 (14), 1620 (18), 2045 (3), 2863 (2), 2871 (5). Salimena-Pires FR PCD 2168 (4). Santos AKA 4 (9), 425 (22), 427 (14), 430 (2), 451 (27), 1084 (8), 1085 (10), 1083 (17). Santos TR PCD 5848 (3). Stradmann MTS 1138 (17).
} 